\title{
Corruption in Action in an Emerging Democracy: The Case of Socio-Pragmatic Metaphors in Cameroon English Usage
}

\author{
Willie Mushing Tamfuh \\ Department of English Modern Letters, Faculty of Arts, Letters and Social Sciences \\ The University of Ngaoundéré, Adamawa Region, Cameroon \\ E-mail: mustamwill@yahoo.fr
}

Received: January 11, 2021

Accepted: February 19, 2021

Published: February 28, 2021

doi:10.5296/ijl.v13i1.18170

URL: https://doi.org/10.5296/ijl.v13i1.18170

\begin{abstract}
In recent times, the Cameroon society has witnessed a decline in social and moral values, which has greatly influenced people's use of language. Over the years, English has equally witnessed a degradation of the language to such an extent that one can talk of corrupt language. Corruption is a key subject that has gained the keen attention of political and social scientists as it affects the political, economic, social and cultural life of a society. This paper sets to identify the systems or rules and conventions according to which the language of corruption operates and concerns the semantic description of the typical words and expressions Cameroonians use to denote this practice in contemporary Cameroon. The idea is that the language we use is a reflection of the society in which we live and a representation of the social reality. This investigation aims to identify, collect and analyse specimens of utterances characteristic of corruption vocabulary and to describe this form of language use from a socio-pragmatic perspective. The scope of study is limited to establish a relationship between people, the language and a complex multilingual society as Cameroon. Data was collected from both oral and written sources as a representation of the opinions gathered from a cross section of Cameroonians. The significance of our study lies in the linguistic description of some characteristic of corruption related discourse. Using the participant observation, both spoken and written data were collected from different sources from the vantage point of functional lexicology and cognitive linguistics. A combination of different known theories, notably; the variation theory, speech act theory, lexico-semantics and the Pragmatic theory relevant to describe an utterance as a speech forms capable of a communicative performative action.
\end{abstract}


Findings reveal that corruption is ubiquitous, corrosive and a dishonest deviant behaviour that severely damages personal and national reputation. To counter this, those engaged in the practice use different speech features such as borrowings, coinages, synonyms, clichés, metaphors and euphemisms. Metaphors and euphemisms are indirect ways speakers communicate important information. The language of corruption is strikingly similar in its soothing, euphemistic tone. Inadvertently, as language users have developed myriads of indirect and camouflage ways to refer to corruption, the language of corruption is also developing its own lexicon and linguistic features.

Keywords: Corruption, Communicative act, Emerging democracies, Metaphor, Socio-pragmatics

\section{Introduction}

Contemporary Cameroon society has witnessed a decline in the social, moral values leading to hate discourse, and tribalism, and affecting different areas in the life of the people. One of the most affected areas is that of language usage and its decline, which has greatly influenced people. Over the years, this situation has given rise to a variety of speech referred to as corrupt language, a practice that remains preoccupying to several emerging democracies in Africa as it affects the political, economic, social and cultural life of the society. Language use is a kind of mirror of the society. Language usage and use are aspects of linguistic performance interested in. Describing corruption, from this linguistic perspective is an attempt to underscore the important role of language usage and use in the accomplishment of the act. This sociolinguistic situation is concerned with investigating and identifying those typical lexical structures; words and expressions Cameroonians use to denote this practice in contemporary Cameroon. The idea is that the language we use is a reflection of the society in which we live and a representation of a social reality. The point is that when we acquire a language we do not only learn how to compose and comprehend correct sentences as isolated linguistic units of random occurrence; we also learn how to use words, utterances and sentences appropriately. In normal circumstances in daily life, the use of these structures manifests our knowledge of the language system. Language changes because people who use it constantly change their minds and try to express their thoughts as accurately and satisfactorily as possible.

Sociolinguists have demonstrated that language use has to do with reality and categorization: it stores the mental and cognitive categories with which human beings perceive, communicate and make sense of the world. 'Language is a translation of reality, a transposition in which particular objects only appear through the intermediary of the organisation and classificatory efforts of thought.' (Note 1) Language, then, is not autonomous; it is linked with the total set of cognitive capacities that enable people understand the conceptual framework of the world. Meaning consists of cognitive categories of the language user and if this opinion is tenable, then language categorises human experiences into linguistic structures.

Saussure's views (Note 2) concerning the study of language were introduced to scholars throughout the world in which he rejected the nineteenth-century notion that linguistics 
should be primarily historical and comparative, and disagreed with the idea that substantial effort should be made to identify, codify and promote the standard form of any national language; he felt it was more worthwhile to focus on describing language as it exists at a given point in time and space, and that such scientific activity be conducted in an impartial manner. For Saussure, three aspects of language are potential objects of any linguistic study, and he uses the French words langage, langue and parole to designate these aspects. Langage refers to the anatomical ability and psychological need or urge of humans to create a system of linguistic signs for expressing ideas. While Langue represents a system of rules, usages, meanings and structures that are products of the human ability to create language and are shared by members of a specific speech community, Parole is often equated with speech. It is the concrete realisation of a collectively-internalised system and also reflects the personality, creativity and physiological capabilities of an individual speaker. Overall Saussure paid little attention to langage, considering it the subject matter of other fields of inquiry, and he regarded parole as too idiosyncratic. Instead, he believed that linguistics should study langue in order to gain a picture of the comprehensive, complex, ordered assemblage of sounds, words and syntactical units in the language. Making use of a concept suggested in the writings of the French sociologist and philosopher Émile Durkheim, Saussure viewed language as a social fact. Saussure understands of the nature of language and his belief that scholarship should focus on investigating the abstract systematic principles of language instead of researching etymologies and language philosophy led to a revolution in the field of linguistics. One of such abstract systems worth examination is the language of corruption in Cameroon, that is, the study of 'parole'; the actual oral and written communication used by its members to enact it, and langue, the system of internalized, shared operational conversational rules. There is a general outcry as to the intensity of the manifestation of corruption at virtually all levels of the Cameroonian society. Consequently, it did not take much for GERDDES-CAMEROON to convince the Friedrich-Ebert-Stiftung as to the pertinence of the subject. Its devastating consequences for the Cameroonian society, the economy and, on the behaviour of citizens in general cannot be overemphasised when language use is a reflection of a society.

This investigation aims to collect and analyse specimens of utterances characteristic of corruption vocabulary and to describe this form of language use from a socio-pragmatic perspective. This paper sets to identify the systems or rules and conventions according to which language of corruption functions. In the Cameroon context, language users have developed myriads of indirect and camouflage ways to refer to corruption. The scope of study is limited to establish the relationship between people and the way they use language in the event of corruption in a complex multilingual society as Cameroon. The significance of our study lies in the linguistic description of characteristics of corruption related discourse in line with Saussure's concept of language study.

But the practice of corruption is not specific to Cameroon alone, but it exists in several countries all over the world. Each society has well thought out rules that establish a bond between the individuals and society, but when this bond is rupture, it becomes a public threat to nation building. The study of the relation between language and corruption in Cameroon remains crucial to the connection between language and the society in which it exists. 
Perhaps because the act of talking is obvious, many people are unaware of the implications in the meaning utterances carry in everyday social interaction. Old words assume new meanings and new words express new experiences, social reality, cultural patterns and values of the people. In instances of corruption, language users carefully select the appropriate words they use though listeners rarely observe the words employed, taking it rather for granted, as walking, eating or breathing are. Little attention is paid to the underlying implications of the acts that occur. Speech acts vary from one speaker to another and from one context to another. In everyday social interaction, we inform, refer, relate, agree, declare, suggest, create, imagine, propose, regulate others' behaviour, and sometimes these speech acts occur with overlapping functions. These overlapping functions occur when one utterance can perform more than one function at the same time; be informative, referential, personal, relational, regulative, creative, and imaginative. We all face similar interpersonal situations both at work, in the market, church, etc., when we are not sure what the right thing to say or do is. Nevertheless, social behaviour is based on a code of conduct with necessary provisions people must follow to understand what the matter is really, and to act accordingly. A social code of conduct defines the values and rules which govern the way we co-operate, relate and behave with others in terms of expected and unexpected social behaviour. Social relations can be strongly established through the use of language, and equally destroyed by the choice and intention of the words we use with others. In effect, the sociolinguistic situation of Cameroon contributes to this state of affairs.

Describing the complex linguistic situation, social scientists consider Cameroon 'Africa in miniature,' and also a complex ethnographic paradise. Breton and Dieu (1985) in Atlas Linguistique du Cameroun, assert that Cameroon's multilingual situation is identical with its ethnic diversity and linguistic situation (Breton and Fohtung, 1991). Africa has a little over 1000 indigenous languages, and Cameroon's linguistic situation is as impressive as a linguistic paradise, accredited with English (Eng.) and French (Fr.) as official languages with 279 attested indigenous languages added to Cameroon Pidgin English (CPE). It counts over 280 languages spoken and about three hundred (300) ethnic groups that enrich the vocabulary system. The use of English (Eng.) and French (Fr.) as two official languages give it a rare bilingual status in the world compared only to Belgium and Canada. This multilingual and multiethnic setting paints an unparalleled linguistic dynamism and complexity in which corruption is practiced. While this situation enriches the linguistic landscape, it also provides a plethora of linguistic choices from which speakers can draw to manipulate speech in favour of corruption. Several surveys reveal that CPE is one of the richest linguistic resources available to every average Cameroonian, irrespective of linguistic, social, regional nor cultural background. CPE remains by far, a de facto language of wider communication. Though not an official language, it is the most widely used language at home, school, street, pop and gospel music, market, work places, entertainment, government offices, political rallies, bribery and corruption, hospital, church, print media, advertisement, on Radio and TV programmes, local newspapers, literary works, and phatic communion in Cameroon. Today, CPE occupies an important place in corruption as the language of expression in both in-group and out-group communication, according to Mbangwana (2012) (Note 3). As a result, CPE continues to serve as the most widely used means of 
communication in Cameroon, and considered an out-group language for Cameroonians of all walks of life and levels, which partly explains its prevalence in the language of corruption. However, English, French, CamFranglais (mixture of English and French grammar) and Cameroon indigenous languages have equally enriched corruption vocabulary as speakers continue to develop new concepts and meaning with new experiences.

The study is carried out against such complex multilingual context. Understanding the language of corruption against this background easily presents the sampling population and informants concerned. From a linguistic perspective, corruption can involve anyone irrespective of gender: from politicians, the judiciary, executive and legislative officials, public servants, students, business people etc., except perhaps children. The spoken data was obtained this sampling population and the written data from publications, newspapers, magazines etc. Particular attention is given to the choice of words and utterances speakers use and their significance and the different underlying shades of meanings. A significant contribution in this light is that of linguistic philosophers who hold that language use is an intriguing mystery and a manifestation of the complexity of human mind and thoughts. In casual conversations, for instance, many listeners pay little attention to the 'slippery' nature of the utterances. A word may have one meaning and different senses depending on the context. In other instances, one word may have more than one meaning. It is important that speakers of a language possess two sets of abilities: the knowledge they have acquired of the language with its internalised system of rules, and equally know how to use this knowledge in accomplishing set objectives in life.

Except for the choice of words and expressions speakers use, bribery and corruption is not always carried out overtly for fear of reprisals. Mostly carried out in private discussions, this illicit social and moral practice is punishable by the Cameroon law. Corruption is ubiquitous, corrosive and a dishonest deviant behaviour that damages personal and national reputation. To counter this, those engaged in it tend to vary the practice using different speech features such as borrowings, coinages, synonyms, clichés, metaphors and euphemisms. Particular attention is paid to metaphors and euphemisms as indirect ways speakers send and receive important information. The language of corruption is strikingly similar in different countries in its soothing, euphemistic tone. Auden noted that 'There is one evil which should never be passed over in silence, but be continually publically attacked and that is the corruption of language' (Note 4). Corruption flourishes in a society where social and moral values are shunned, and given way to impunity and reckless social behavior. Corrupt language corrupts thoughts. The language of corruption has taken on its own vocabulary, linguistic ethos and pathos, which require an indepth socio-pragmatic consideration.

Saussure advocated a synchronic examination of language. Not interested in studying a particular language or the linguistic habits of any one member of a given speech community, Saussure sought to examine language in general and to identify the systems or rules and conventions according to which language functions. Saussure's views on language influenced linguistics during the twentieth century, and his imprint can be found in theoretical works discussing phonetics, phonology, morphology, syntax, pragmatics and especially semantics. Saussure rejected the nineteenth-century notion that linguistics should be primarily historical 
and comparative, as well as the idea that substantial effort should be made to identify, codify and promote the standard form of any national language. He felt it is more worthwhile to focus attention on describing language as it exists at a given point in time, as it is intention of this paper.

Before we proceed any further, it is important to define some of the basic key concepts highlighted in the study such as, 'corruption', 'metaphor', 'communicative', 'socio-pragmatics', and democracy in order to throw more light on the way they are intended to be understood.

The Merriam-Webster Dictionary of English defines language as a system of communication in which people use words or nonverbal signs to express their thoughts, emotions and feelings. The act of communication is a system of words, actions, or signs people use to say what they think, and how they feel in different situations. A communicative act is an utterance or set of utterances (communicative act set), that we use to perform some sort of linguistic action or function in communication. The meaning of any communicative act is influenced by non-verbal signals such as gestures and even silence. By corruption in action, reference is made to the utterance or set of utterances (communicative act set) that are used to perform this sort of linguistic action. Speech acts are verbal actions that accomplish something. Informatives: we greet, inform, regreet, insult, agree, disagree, request, order, persuade, compliment, plead, flirt, supply information, and get work done. Representatives: assertions, statements, claims, hypotheses, descriptions, suggestions. Commissives: promises, oaths, pledges, threats, vows etc. A speaker's diction includes the types of words and phrases he uses in speech or writing with respect to the topic, setting, code, and audience. For instance, 'I need kolanut.' But what is 'kolanut? Which type of kolanut'? Why does he need kolanut? Note the metaphorical sense of 'kolanut' which may refer to an object or idea in such a way that it appeals to different physical senses. A speaker's diction is effective when the appropriate words are used, whether they are simple or complex structures. Sometimes, a figure of speech can be used to beautify the piece of speech by comparing two dissimilar objects as in metaphors to test the very understanding of the listener. Usually, in such circumstances, the imagery provoked by the metaphor uses particular words to create the visual representation of the idea in our minds. "Imagery" is associated with creating mental pictures of abstract ideas in a listener's mind. (Mbangwana. The imagery associated with the word 'kolanut', is more realistic and complex than just a picture. In general, speech acts are acts of communication. To communicate is to express a certain attitude, and the type of speech act being performed corresponds to the type of attitude being expressed. For example, a statement expresses a belief, a request expresses a desire, and an apology expresses regret. This justifies the sociolinguistic view that language in use embodies and represents social reality and not a mere structural unit. (Note 5)

The term 'corruption' is derived from the Latin verb rumpere or 'the act to break', ruptures or disentangle something established to denote a deviant form of behaviour. The non-respect of generally agreed rules creates a rupture; it can be a social, moral or ethical code, even an administrative rule. Transparency International (TI) (Note 6), defines corruption as a; 
'misuse of entrusted power for private gain.' Corruption is a form of dishonesty or criminal offense undertaken by a person or organization entrusted with a position of authority to acquire illicit benefits.

Generally, the abuse and violation of entrusted power for private gains is a deviant form of social behaviour. While being corrosive, it erodes trust and relations, weakens democracy, hampers economic development and further exacerbates inequality, poverty, social division and the environmental crisis. From several studies, the basics are that corruption can take many forms, and can include behaviours like:

- $\quad$ public servants demanding or taking money or favours in exchange for services,

- politicians misusing public money or granting public jobs or contracts to their sponsors, friends and families,

- $\quad$ corporations bribing officials to get lucrative deals

As a deviant practice, corruption is connected to the rupture and failure to adhere to some conventional social standards and individual behaviour including the use/abuse of physical objects against the cultural norms of society. Based on the abovementioned facts, any communicative act can be described as corrupt when:

1. the act has to do with people occupying authority positions of public or private trust;

2. the committed act negates the laws, regulations, values, and norms of society; and

3. it is intentionally carried out to promote private interests and intentions.

Note that corruption is seen as any unlawful or improper behaviour undertaken with the deliberate intent of extracting personal rewards and to gain an advantage over others through illegitimate means as bribery, abuse of power, extortion, fraud, facilitation payments, deception, collusion, cartels, embezzlement and money laundering as different forms of corruption. For example, facilitation payments are sums of money paid to speed up or "facilitate" their actions or documents, sometimes referred to as "motivation', "grease" or "speed" payments. Corruption can happen anywhere; in business, bus stations, public services, the courts, the media, and in civil society, as well as across all the other sectors from health, Transport, public contracts, and education to infrastructures and accusing fingers point at several public sectors, the Ministry of Finance at the top, the customs department, public contracts, the Police, Gendarmerie, competitive entrance examinations into some professional schools, etc. Here, there is evidence of officials in high positions who abuse entrusted power to serve their personal interest. The lieu may vary, public and private places include office spaces, markets, beer parlours, schools, churches, workplace, the radio and TV, music, naturally occurring speech, etc., but their modus operandi or operational code, par excellence, is communication. Transparency International (2019) describes six most common types of service corruption, including; absenteeism, informal payments, embezzlement, inflating services and the costs of services, favouritism and manipulation of data. These acts are used with the deliberate intent of extracting personal and/or private rewards against the interests of the state. Regarding the method, corruption happens in the shadows, often with the help of 
professional enablers such as bankers, lawyers, accountants and real estate agents, opaque financial systems that allow corruption schemes to flourish. There is reciprocity between the briber and corrupt.

The term 'socio-pragmatics' used here refers to that aspect of language which studies the contextual meaning of the words people use in everyday social interaction. This approach is grounded in the way in which utterances which are not related formally are understood by recovering the communicative activity they represent and discussed in the study of language in its social context. (Note 7) Interpersonal conversations provide the appropriate context in which speech occurs naturally and highly considered in speech analysis in such disciplines as pragmatics, conversation analysis, and discourse analysis. Pragmatics refers to "the ability of language users to pair sentences with the contexts in which they would be appropriate" (Levinson 1983) (Note 8). For example, goat di chop for place where dem tie ye." Pragmatics provides utterances used in specific contexts with indepth meaning. A metaphor is a communicative set of speech in which an expression is used to refer to something that it does not literally denote in order to suggest a similarity. The metaphor asserts that two things are identical in comparison to establish a similarity. In this CPE example, "goat' is compared to a civil servant," and place where dem tie ye' relates to his workplace and there is a relationship between a 'goat' and 'where dem tie ye'; the principal term is "goat" and the secondary term is "place of work." The term 'place where dem tie ye' adds a sense of flavour to the goat to convince the listener that the worker eats where he works. In this example, the speakers use the 'goat' as concrete images to describe abstract truths especially when seeking for appointment. It may refer to anything but a goat. It may be a cow, a car or money.

The term lexicology first appeared in the 1820s and composed of two Greek morphemes, "lexis" which means "word, phrase" and "logos" - which denotes "learning a department of knowledge." Thus, the literal meaning of the term "lexicology" is the science of the word. In this study, the term 'word' or 'utterance' denotes speaking as the act of communication resulting from the association of a group of meaningful sounds. The term 'word-group' denotes a ready-made unit of language used, 'fix me', 'shake skin' that has the unity of meaning and the unity of syntactical function. Technically, in this context, a word is a composite of one or more morphemes, each made up of one or more spoken sound units. Words are the meaningful units in a language, and can be used independently, as complete meaningful units, 'mouillir la barbe' as they are always parts of a larger structure. Every word has the outer aspect, the sound structure and the inner aspect, the meaning. An utterance has both sound and meaning and language serves as the medium of negotiation or enactment. In our data, not only do speakers use of simple words or phrasal structures, the vocabulary contains metaphors, euphemisms, idiomatic expressions and short texts charged with meaning.

This present study is structured in eight sections. It begins by presenting a general introductory background including the research problem, aim and objective (s) of the study, the scope and significance of study and the definition of some key words. Section 1 is a review of the literature. Section (2) deals with the methodology followed, including techniques of data collection, classification, and treatment while Section 3 handles the 
theoretical orientation of the study, which is eclectic. Section (4) handles the data analysis, and interpretation as a linguistic metaphor. Section 5 treats sense and reference in the data, and Section 6 handles the pragmatic interpretation of synonyms, polysemy, and metaphors as characteristic features of corrupt language. Section 7 examines corruption as a linguistic metaphor. Section 8 looks at corruption and social values ending with findings, conclusion and recommendations.

\section{Review of Literature}

Recent statistics (Note 9) reveals that while most people in Africa feel corruption is on an increase in their country, a majority also feel optimistic that they, as citizens, can contribute in the fight against corruption. They state that more than half of all citizens think corruption is getting worse in their country and that their governments are doing a bad job in tackling corruption. Several scholars and bankers have been preoccupied with this subject. Elliott, Kimberly Ann (1997); Hudson, J., (2014); Kaufmann, D; \& Vicente, Pedro, (2005) have examined "Corruption as an international policy problem, Bribery and Identity: Evidence from Sudan, and Legal Corruption respectively.

Many studies reveal the extent of corruption in Africa. Several countries stand out for their high bribery rates and corruption levels, with the Democratic Republic of Congo (DRC) highly rated and Mauritius, the lowest rated. Public sector corruption does not exist in a vacuum. It was found that when money that should support critical services such as health care and education, flows out of countries due to corruption, ordinary citizens suffer most. Scholars and commentators have observed that corruption is a major challenge to social and political development in Africa and a major barrier to economic growth, good governance and basic freedoms, such as freedom of speech or citizens' right to hold governments to account. More than this, the situation affects the wellbeing of individuals, families and communities. They postulate statistics as follows; Government officials (39\%), Members of parliament (36\%), President/Prime Minister's office (34\%), Business Executives (34\%), judges and magistrates (34\%), Local government officials (33\%), Traditional leaders (22\%), NGOs (20\%), Religious leaders (18\%). These results are consistent with findings from the 2015 report. Notice that besides the police, corruption is very rampant among government officials followed by members of parliament, judges and magistrates, all top government officials. He concludes that tackling corruption in Africa is herculean and requires a holistic, systemic approach. In many of these countries, the police and national security forces consistently earn the highest bribery rate across Africa. Based on this statistics, citizens opine that the police are the most corrupt institution, with 47 per cent of people believing that most or all policemen are corrupt.

Corruption in Nigeria, for example, constitutes a key subject of debates and discussion among Nigerians from post-independence to date. Affected sectors involve public services like utilities, including electricity and water, and identification documents, including licenses and passports, also have high bribery rates. In a recent work, B. Ekpenyong and V. Bassey (2014) examined the language of corruption and anti-corruption in Nigeria (Note 10) claiming that as human beings, we use language for various reasons primarily related to the way we think and our intentions. Using lexical items recorded, they collected words and expressions within 
Nigeria and analysed these words and expressions in order to describe how Nigerians refer to corruption drawing from written popular and creative literatures. Old words are given new meanings and new words are coined or compounded. He noted that sometimes, one utterance may have varying meanings. These overlapping functions of speech acts may include not only being informative, referential, relational, and regulative, these are also imaginative and creative. The subject has taken its own well-recognised vocabulary (register) that they set out to examine corruption discourse. Their analysis revealed a pool of gradable synonyms, collocates, metaphors, idioms, borrowings, clichés and coinages used by Nigerian to x-ray corruption and engage anti-corruption functions. They conclude by noting that with the large scope of expressions found and used by Nigerians when engaged in the issues. It demonstrates that corruption cannot be wholly understood from a political or economic perspective. In this other study, Inge Amundsen (2019), on the one hand, has analysed political corruption as a distinct but separate entity from bureaucratic corruption. He demonstrates that political corruption includes two basic, critical and related processes: extractive and power-preserving corruption. Evaluating seven key case studies, he illustrates the theoretical basis of corruption and provides a political-economy analysis of the topic, using examples from Sub-Saharan Africa. He separates these two very different social phenomena in a way that is often overlooked in contemporary studies. Outlining how it is enacted and who is involved, these cases provide glaring evidence of political corruption. Amundsen highlights how political corruption undermines the political will to curb corruption, a key area that traditional anti-corruption efforts have failed in.

Igiebor (2019) (Note 11), on his part, examines the effects of corruption on the economic development of Nigeria. He focused on the effect of corruption on Nigerian political leadership, corruption and its implications for economic development. After discussing the sociocultural, political, and economic factors responsible for the endemic nature of corruption in Nigeria, he concludes that the "top-to-bottom" corruption in Nigeria has negatively affected the country's economic development. Proposing that to change this situation, the leadership must genuinely be committed to fight corruption from the top down; corruption control mechanisms need to be strengthened, the offenders need to be punished, and the citizenry needs to be mobilized to demand transparency and accountability. Practically, the difference from country to country is in its dimension, intensity and the way the government and the society at large deal with the problem of eradicating this pandemic. According to Momoh (2013) (Note 12), not a single African country is corruption-free and two-thirds of all the countries measured were perceived to have serious corruption problems that affect the economic, political, social and cultural life of emerging democracies leading to poverty and underdevelopment.

At the time GERDDES-CAMEROON contacted the Friedrich-Ebert-Stiftung for a support to study corruption at the beginning of 1998, Cameroon's corruption Perception Index (CPI) has been consistently poor throughout the history of Transparency International. Corruption practice was at its worst in the late 1998 and 1999 when Cameroon topped the ranking of most corrupted countries in the world followed by Paraguay and Honduras. Nobody could imagine that some months later, the German-based-Non Governmental Organisation (NGO), 


\section{Macrothink}

Transparency International, would render public a Report on 85 corrupt countries ranked Cameroon 153 out of 180 countries (Note 13) Corruption is "Cameroon's worst-kept secret" with "persistent problems with corruption." They found out that the police and national security are seen by Cameroonians as the most corrupt institution. (Note 14) Cameroonians are no longer perplexed that corruption scandals in Cameroon constitute a recurrent topic in all the media. These scandals abound in every conversational discourse, political speech, social media debates and publications that academicians cannot continue to ignore its pervasiveness; affecting all sectors of the Cameroon society, government and civil society including the executive, judiciary, police, and even the private sector. Two main reasons for this include the lack of political will to fight corruption and neo-patrimonialism. Neopatrimonialism is defined as "a type of regime in which ruling elites use the state for personal enrichment and profit from a public administration that is patently unstable, inefficient, non-transparent, and that fails to distribute public resources to large segments of the population." (Note 15) They further point out that in a neopatrimonial state, real power and real decision-making lie outside its institutions. Here, power is held not by high-ranking government officials, but by those who have connections/clientelist networks that exist inside and/or outside state structures (Cammack, 2007). Public office power is used by civil servants, who lack basic social, ethical and moral values as respect for others, honesty and concept of the superior interest of the nation to engage in corruption deals for personal gains. In this system, government officials and members of parliament (MPs) account upwards - to the president - rather than downwards - to the people. In this way, the president controls the local branches and institutions in order to prevent these local institutions/branches to 'rebel' against him. This is done by the central power (the government in general or the president) to maintain a firm grip on power at all cost, even if it means slowing down policy implementation.

Cameroonian academics and political analysts have equally criticised the pervasive lack of accountability in Cameroon administration. When government officials report upwards to the president, rather than downwards to the local people, it creates a situation where government officials are free to do what they want without fear of public judgement (Fometeu (2001) who draws attention that the laws that sanction corruption are not adapted to the corruption environment of Cameroon. Firstly, almost all civil servants in Cameroon are corrupted citizens whether in giving or receiving the bribe for the most basic government services. He regrets that corruption is rampant in Cameroon's judiciary, presenting companies with very high risks. Companies report a high frequency of bribes in exchange for favourable judgments. Judicial officials accept bribes in exchange for dropping charges, a reduction in prison sentences, or a release. (Note 16) Over half of Cameroonians perceive the judiciary to be very corrupt. The judiciary is not always free to independently investigate and prosecute cases of corruption. Judges are susceptible to executive influence and delay judicial proceedings when pressured. Judges and lawyers report frequent harassment, including arrest and detention by government forces. The study concludes that the judiciary is inefficient, lacks adequate resources and expertise and has an inadequate tracking system of corruption cases, resulting in lengthy court delays. The practice is particularly ingrained in the judiciary, public services, and customs. The legal and regulatory systems are non-transparent and 
difficult for foreign companies to navigate. With this evidence, if they decide to denounce civil servants, both of them shall be convicted, which is wrong. Only the civil servant should be convicted because he is in a position of power and he is the one who further proposed to be bribed. Fometeu (2001) points out a number of lapses; the lack of a conviction system proportional to the severity of the act of corruption committed, unwillingness of political leaders to submit themselves to scrutiny, that denunciation should be done freely without fear of backlashes, and the judiciary should be totally independent, insists Fometeu (2001). In addition, there exists a lack of effective regulations, insufficient law enforcement and significant delays in courts. Cameroon's Penal Code (in French) criminalizes corruption, bribery, extortion, and bribery of foreign public officials, and corruption is punishable by a prison term of five years to life, a fine of up to USD 4,000 and/or asset seizure. Facilitation payments and gifts are also addressed in Cameroon's legislation, yet insufficient implementation of the anti-corruption legislation coupled with impunity among public officials has exacerbated the levels of corruption in the country.

These studies have ex-trayed the issue of corruption from different points of view. While NGO's are preoccupied with statistics and figures, Fometeu (2001) like other scholars, concentrate on the political, legal and judicial implications of corruption, with little or no interest on the psychological and linguistic impact of corruption on the individual and the state. Researchers interested in this branch of linguistics have not been unanimous on the relationship between language and society. Despite the various stances held by sociolinguists concerning language and society, which are not necessary in this work, the idea is that the language we use is a reflection of the society in which we live and a representation of this social reality. This stance is also held by some theoretical linguists, who have proposed different concepts as the bases of analysis including the theory of language variation and context (Labov1960), Sapir (1929), Fishman (1968), Trudgill (1974), Wardhaugh (1986), englobing the concept of linguistic variation and language in its social context. Language is somehow a kind of mirror of the society. It is a reflection of a society's [ills], culture and its perception of the world; as it relays information, it demonstrates how a certain society takes in, processes, evaluates, and conveys that information."

However, some Cameroonian linguists have examined corruption in this light to understand how certain words and expressions are used to enact the phenomenon from a purely linguistic perspective the way Meutem Kamtcheung has done. This prolific academician shows keen interest in studying language use and usage in the expression of the Cameroonian sociocultural identity. Meutem Kamtchueng (2019) undertook to analyse the language of corruption in sub-Saharan Africa, focussing on the relationship between language and society. He draws his data from a wide range of languages in the sub-saharan region, noting that the language of corruption in various countries is developing its lexicon and its linguistic features gradually and language users have developed myriads of "hygienic and camouflage ways" to refer to the malpractice. For instance, in many countries, language users have coined various lexes and expressions to refer to bribe (e.g.: "cash for soup" (in Turkey), "token of gratitude" (in China), "money for tea"(in Afghanistan), "beans for the kids" (in Kinshasa), gombo/kola (Cameroon), goro, gbalamu, kua/kwa/kua, awufu, egunje (Nigeria), "glass of wine" (in Paris), "little carps" 
(in Prague), "cup of" kahwe" or coffee" (in North Africa), "tea for elders" /chai ya wazee" (Swahili expression in Kenya), "some things mall/ kituki dogo"(in Swahili),"gratitude" /haalapenz (Hungarian/Mandarin), “oiling money"/Kenepenz” (in Hungary) (Meutem Kamtchueng (2015); Safotso Tagne (2015). They hold that language varies from one public domain to another, although there are some lexes and expressions which cut across all the domains. The scope of their study is limited to some selected countries of sub-Saharan Africa. These countries are chosen among those of East, West and Central Africa. The significance of their study lies in the linguistic description of lexes characteristic of corruption.

In another enlightening study, Meutem Kamtcheung (2011) investigates the semantics and the characteristics of the metaphors used for bribery and corruption by Cameroonians and Nigerians. He set out in the paper to study, from a comparative perspective, the semantics and the characteristics of the metaphors for bribe and discuss factors which account for the choice of these metaphors. The data for the study were collected using the participant observation of speeches, novels, interviews, scientific papers and online sources and discussed from the vantage point of functional grammar and cognitive linguistics. The findings of the study reveal that in order to lessen the appalling nature of the act of asking for bribes, avoid sounding ridiculous and render incomprehensible the message of asking for bribe from people who are not familiar with it, these language users utilize various types of metaphors (object metaphors, anthropomorphic metaphors, vegetative metaphors as well as zoomorphic metaphors). These metaphors display some similarities (which can be accounted for by the geographical proximity between the two countries) and differences: both utilize almost the same types of metaphors and to a lesser extent the same lexical items to refer to bribe but in different proportions (object metaphors, anthropomorphic metaphors, vegetative metaphors as well as zoomorphic metaphors). Furthermore, it is found that the values conveyed by these metaphors fall under the domains of foodstuff and drinks, fauna, human beings and body parts, mailing and transportation as well as abstract realities. For example, the utterance 'give an envelope for the boss'/Give a brown envelope for the boss' carry the same message though with slight modification on the semantics and characteristics of bribes across cultures using Cameroon and Nigeria. Some of these metaphorical speech acts can be characterized as being meliorative, pejorative, vindictive and kinaesthetic. Moreover, he found that cultural, social and economic factors can provide insights to the understanding of the choice of the values of the expressions used to refer to bribe by these language users. In addition, the values used to represent bribes in these countries are a depiction of their multilingual complex nature.

In yet another study, Meutem Kamtcheung carried out a linguistic study of the language of corruption in Cameroon, underscoring that corruption has eaten deep into the fabric of the Cameroonian society.

His paper studied the various linguistic hallmarks which characterize the language of corruption in the spoken and written productions of Cameroonians. The data was obtained from different sources, observation, interviews, online sources as well as printed materials. Using the participant observation, a wide range of spoken data was collected, and he provides several sample data for example, 'Give the envelope to the boss', 'C'est ca que je mange?/Is 
that what I eat?' Such examples testify that corruption prevails and language is a reflection of the society in which it is used. After the analysis, he came out with several findings amongst which are the following; that the language of corruption is characterised by such linguistic features as semantic shifts, metaphors, synonyms, borrowings, affixation, idiomatic formation and stereotyped sentences; that the language of corruption draws its lexical constructions from existing English, French, Cameroon Pidgin English, and Cameroon home languages. However, that French is the language from which the most sizeable proportion originates. This imbalanced proportion is attributed to the dominance of the French language in the Cameroonian administration system. His findings reveal that language users utilize various linguistic resources in order to make a request, receive or accept bribes; sharing the fruits of corruption; fighting against corruption; searching, maintaining and consolidating corruption networks; showing relationship and acquaintances; justifying acts of corruptions, etc. Some of the linguistic constructions which are at work in the language of corruption include the following: semantic shift, euphemism and metaphors, borrowing, affixation, idiomatic formation, stereotypical sentences, etc. Besides, it is very probable that the contribution of languages to the lexicon of the language of corruption accounts for the sociolinguistic situation (i.e., the statuses and the power relationship) of the languages spoken in each country. The linguistic resources used to refer to the practice of corruption shows the dynamism of the language of European importation into then non-native contexts. The findings reveal that in order to lessen the appalling nature of the act of asking for bribes, avoid to sound ridiculous, speakers clearly introduce a new word, synonym, metaphor or euphemism. He identified various types of metaphors including object metaphors, anthropomorphic metaphors, vegetative metaphors as well as zoomorphic metaphors.

Expressing Orwell's views on the state of politics and language, Miller (2019) looks at the psychological effects of words on human thoughts and politics. He demonstrates that people in high political positions as politicians abuse their entrusted language power to manipulate their subjects for personal gains. Orwell's (1946) view of the English language and politics is that the language of politics is designed to make lies sound truthful and murder respectable, and to give an appearance of solidity to pure wind. He asserts that political language is expressed in sloven, vague or meaningless words because it is intended to hide the truth rather than express it. That is, one says one thing and means something else. Corrupt language would corrupt thought, and if language is corrupt, it can affect the society. Doublespeak is language that pretends to communicate directly by hiding his intentions in euphemisms, and convoluted phrases. Doublespeak makes the bad seem good and the negative appear positive and corrupt thoughts appear polite, witty, and crude. If language can corrupt thought, then it can control the listener's mind and actions. Orwell consistently argues that English language is deteriorating with exhaustive, convoluted phrasing and outdated metaphors and similes that hold little meaning to the audience. As a result, the speaker makes use of utterances that can easily condition the listener's thoughts. Orwell warns that the slovenliness of our language makes it easier for us to have foolish thoughts, lamenting the fact that "bad usage can spread by tradition and imitation even among people who should and do know better. The use of vague expressions makes language insincere. Orwell stands for a reform to language by adding words to describe the indescribable and removing archaic 
or unused words that are not consistently used in language. Laying the groundwork for language reforms, Orwell (1946) (Note 17) argues that the great enemy of clear language is insincerity. Here, there is a gap between one's real speech act and one's declared aims like a cuttlefish squirting out ink." He points out that "if thought corrupts language, language can also corrupt thought." Also in 1984, Orwell reiterates the concept of doublespeak or evasive language in "Politics of the English Language." Doublespeak allows for a statement to be supportive and contradictory all in one. When Syme states, "There is a word in Newspeak, I don't know whether you know it: duckspeak, to quack like a duck Orwell $(1984,54)$ (Note 18). What an interesting word that have two contradictory meanings. Applied to an opponent, it is abuse; applied to someone you agree with, it is praise" (Orwell, idem). Doublespeak becomes dangerous in the hands of the political elites where a politician may say one thing and mean another and he believes that this manner of thinking is completely irrational and insincere. Linguists are preoccupied with linguistic meaning; but how can one say one thing and mean something else? Every language forms a unique symbolic lexical system different from other systems as syntax and semantics. At the start of a new academic year, parents negotiate with principals/directors for admission in school; sometimes, young girls give 'something' undefined object (an envelope or sex) and young men have to pay a fabulous sum referred to as 'envelop' for admission into professional schools or jobs.

\section{Methodology}

Different research methods were used to collect the data, two main types of data were collected, the spoken and the written. Both the direct and indirect methods of participant observation prescribed in ethnomethodology were employed. Having observed that people use a specialised diction for corruption, using a direct participant observation technique of naturally occurring speech, most of the spoken data was obtained during casual conversations, discussions and interviews. The spoken data obtained consists of specimens of lexical units; that is, words, utterances occurring in natural speech, commonly heard and used by a homogeneous cross section of the Cameroonian society as the sample population. Their ages range between 20 to over 60 years. The informants whose speech we recorded were identified by indiscriminate random sampling. All the informants are of Cameroonian nationality in the public sector, notably; Civil servants of the public service, members of the military, forces of law and order, the educated class, Members of Parliament, students, law reinforcing officers, or top manager or a worker in the private sector; entrepreuneurs, lawyers, etc., . Conversations are spontaneous and can occur in any place the conversationalists deem necessary, be it in the office, beer parlour, market, at school, etc. A greater part of the data consists of simple words, utterances, compound and phrasal structures. A few are proverbs, metaphors and euphemism. The study of linguistic variation focuses on the way people use words as lexical items and their meaning. The speech of children were not part. Children have neither mastered the use of metaphors, euphemisms nor idioms as to participate in the study. Consequently, the speech of children below this age-range and that of foreigners were exempted in the survey.

To obtain authentic spoken data, the ethnographic participant-observation method proved useful. The data was recorded in the language it was used as English, French, Cameroon 
Pidgin English or in some Cameroon home language such as makalapatti', mouiller la barbe', 'tchoko', '10\%', 'gombo' etc. Instances of conversational discourse provide relaxed situations for discussing with others about daily personal and important political and social issues. And sometimes, perhaps because of its familiarity, people rarely observe what is going on, but take each word uttered rather for granted. The words we use have strong influence on the listeners. In naturally occurring speech, the utterances collected were often single words, word-groups or short phrases and were recorded as produced. Most of the data were collected as people participated in conversation and group discussion, as spontaneous conversations, radio broadcast, television debates and discussions provide various communication channels. Casual conversations allow speakers air out their ideas without fear. No doubt, face-to-face social interaction and group discussions offer real life situations for speakers to express their ideas and experiences on different sensitive topics as corruption in Cameroon. Utterances as 'makalapatti', mouiller la barbe', '10\%', 'gombo' etc., are commonly heard in everyday social life. This direct method of observation offers first-hand information, and enables the researcher to monitor the actions, attitudes and moods of the speaker. Lexical semantics studies the characteristics of words and utterances in larger streams of language use as casual conversations, discussions, debates and written discourse. It examines how words take significant meaning in spoken and written discourse.

The library research carried out was quite helpful to update data and refresh the literature review and evaluate what exists on corruption. Beside the tape-recording utterances in naturally occurring speech, other reliable sources of information include published materials. These sources include the different texts compiled from different written publications for this particular study from a wide range of books, national and international reports, magazines, and newspapers, literary productions, novels, interviews, scientific papers and online sources and the work is discussed from the vantage point of socio-pragmatic linguistics. They are mostly reports from CONAC Bulletins (2010-2012-2013, 2020), Cameroon Corruption Reports (2020) and non-governmental organizations (Transparency International). Other sources of written documents were gotten from the print media; newspapers, magazine, scientific papers, and literary works. Most of these publications equally give examples of what people say. Written texts also provided interesting information on the subject. From the published data collected, short texts do not always strictly observe the rules of grammar and syntax. Although corruption is a universal phenomenon, each country develops its lexico-semantic constructions to refer to its practice. Most of the short texts were usually single words, verbal phrases, and ambiguous with insufficient linguistic signals except perhaps the concrete noun used as 'fuel', 'how'. Speech production is not the mere uttering of words as many people think, but performatives push listeners to react. Saying to John simply 'Come here' is asking John to actually displace himself towards your direction. Even though it is a request to perform a certain action, it is an imperative. Cognitive words express human experiences, thoughts, intentions and enables the listener to act appropriately. In everyday conversation, it is common place to hear people use the following pidgin English utterances "tchoko", "fix me", "mouillir la barbe", "goat di chop for place where dem tie ye”, "crash ma back I crash ya back", "fuel", "palm oil" and "grease the wheels" etc., just to name these few. Though each utterance means something unique, they point to a kind of persuasive 
speech acts. It is normal to classify them as suggestions, though the degree of suggestions vary from mild asking to proverbal and advice. During social interaction, most listeners are unaware of the breath, depths and implications of some of the words and utterances speakers use, and oftentimes ignore that these words and expressions are polysemic; charged with possible multiple interpretations. To say a word like "tchoko", "fuel", or "goat' can have different meanings is to rely on the view that language use is cultural and conventional, sometimes arbitrary. From its literal sense, the listener may understand that normally, he is required to scratch the speaker's back, and does that, whereas the speaker's intention is to draw the listener's attention that to offer something to someone is good as one good turn deserves another. 'Mouillir la barbe' does not suggest that 'water is poured on the beards as some may think, but it implies that something (money as bribe) or motivation is expected for a service to be rendered. Equally, 'Fix me' suggests that all is not going on well and there is need for fixing. Thus, their frequent occurrences in the daily speech of Cameroonians calls for attention. On the whole, there are very few long utterances except as proverbs. Knowledge of pragmatics is needed to understand short texts. Since 1990, the English and French Cameroon media landscape is always saturated with corruption scandal captions such as; "Memve'ele, 20 milliards détournés" (Note 19), "La liste de pilleurs selon la CONAC," (Note 20) and "Ces ministres qui défient CONAC," (Note 21) etc. For many centuries today, corruption is an old practice. The choice and use of these words in this headings reveal a disgusting public opinion on corruption in Cameroon. Words as "détournés', 'pilleurs", "défient", signify different forms of corruption practice including 'embezzlement', 'stealing' and 'defiance' or the 'non-respect of law, all of which involve top government officials, reasons why the World Bank has described corruption as "Un cancer resistant au Cameroon." (Note 22) Understanding the meaning of the word 'un cancer' in this short texts is not often easy. Is it the terminal disease or an irresistible practice? Note that words are references to things without intending the word to be the thing

In addition to the tape-recordings of spoken and written data, including library research, a total of over 200 questionnaires were formulated to ascertain corruption and equally distributed to be filled and returned by potential informants. Twenty questions were formulated in four different parts intended to find out what speakers think, say and do about corruption in Cameroon. Various types of questions were set, both open and closed questions were asked with focus on identifying specific vocabulary and expressions denoting corruption. A part was reserved for multiple choice questions. Out of 200 questionnaires distributed to the informants, 181 were returned and analyzed. These various methods enable the researcher obtain authentic and quality data, one that reflects the social and linguistic reality of language users in Cameroon. Lexical semantics, also known as lexico-semantics, consists of a subfield of descriptive linguistics, capable of handling the meaning of both simple and complex lexical units that occur in corruption speech event. It is concerned with the choice and use of words as communicative act with subtle shades of meaning in the language.

A data specimen of fifty communicative acts (both spoken and written) were collected as text for analysis and classified into three groups as sample data, simple words $[1-12,16,24$, 
$37,40]$, verbal structures [13, 14, 15, 17-23, 25-30, 38, 41, 42, 43] and word-groups [32-36, $39,44,45,46,48,49,50]$. An adequate understanding of how these words and utterances acquire their contemporary meanings require a thorough knowledge of the social and pragmatic knowledge of conversational analysis.

\section{Theoretical Framework}

Theoretical linguistics is often associated with the study of language and social variation, the speech act theory and conversational analysis of such linguists as Plato, (Cratylus, 427-347 B.C.), Labov (1960), Sapir (1929), Grice (1975), Austin (1962), Searle (1969) and Levinson (1986), respectively as related concepts of language use and usage. These theoretical concepts date as far back as the Philological etymological linguists notably from Hermogenes, Socrates and Plato to linguistic philosophers like Wittgenstein (1952) and Austin (1962). who were interested in the study of words, their etymology and the triad relationship between things referred to, the words which name them and their significance. After all, the use of language is a natural spontaneous unconditioned phenomenon, and not conventional, but subject to appropriateness in use Cratylus (383a, 383c-d). To them, words are powerful linguistic forms meant to be used as a 'convenient shorthand to communicate complex ideas, experiences and perception. It is natural to say things the way they appear, drawing from the biblical Adamic myth of naming things. So whatever name you give to a thing is its right name; and if you give up that name and change it for another, the later name is no less correct than the earlier. These linguistic philologists claim that the names of things should be 'right' in a very fundamental sense: and should express the natural essence of the thing named. Examples illustrating the non-conventional, non-arbitrary nature of words abound. Why, for instance, is 'theous' the name for 'god'? 'Theous' and 'god' must refer to one and the same person. Assuming that words are essentialist descriptions of the things they name, but at the same time taking for granted that the superficial form of the word as it has come down to us may hide its original significance. For example, the concept of God is extensively divergent. While the English name him 'God', the French say 'Dieu' and the Wimbum refer to him as 'Nyu' and in Dii as 'Tai'. In Islam he is named Allah. In christaindom, he is named Jehovah El Shaddai, Jehovah Nisi, Yahweh, YHWH, Yahwe, Yahveh, YHVH, Yahve, Wahvey, Jahvey, Jahweh, Jehovah, JHVH, YHWH, YHVH, Jehovah, etc. As such etymological analysis would search for the hidden original meaning of words. In other words, linguistic studies would always seek for the truth. In essence, he is the supernatural being conceived as the perfect and omnipotent and omniscient originator and ruler of the universe; the object of worship in monotheistic religions, also referred to as creator of the universe.

The 'Analogists believed that the origin and the true meaning of words is the investigation of etymology. For instance, the word 'blackbird' obviously consists of 'black' and 'bird'; the species was named for its colour, and, indeed, blackbirds are birds and are black. Assuming that words are essentially descriptions of the things they name, but at the same time taking for granted that the superficial form of the English word may hide its original constitution, for not all blackbirds are of this specie. The Greeks, in a word as 'gooseberry' would have concluded that there is some deep-seated connection between 'berry' and a 'goose,' and it is the etymologist's task to find the connection. Is 'goose' and 'berry' connected? What about 
'strawberry' and 'blueberry'? The case of 'mushroom' presents more difficulties because it is hard to connect 'mush' to 'room'. From Middle English, from Old English god (“deity”) (akin to Old High German got (a rank of deity)), originally neuter, then changed to masculine to reflect the change in religion to Christianity, both from the Proto-Germanic *guda (compare Dutch god, German Gott, Danish gud), from the Proto-Indo-European *'gh uto- ("invoked [one]") to Proto-Indo-European *g'hewH- ("to call, to invoke"). The ancient Greeks had the gift of wondering at things that other people take for granted and boldly speculating about the origin of words, history, and the structure of language. Their views are concerned with the question whether the relation between things and the words which name them is natural and necessary or merely the result of a human convention. No matter the religion or conviction, they all describe a deity, akin to Old High German 'got' and Christian 'God' as the "invoked [one]" everybody calls and looks unto for existence. The century-long controversy between the 'analogists', who believed that language is natural, regular and logical, and the 'Anomalists', who denied these things pointing out the irregularities of linguistic structure remains crucial.

Linguists of the early nineteenth century straightforwardly reconsidered this view of analysing a word by considering its origin. These etymologies later acknowledged that, at any rate, speech forms change in the course of time and linguistic description cannot be limited to speculations, but on a careful study of lexical and semantic change in language. Bréal's (1897: 124) (Note 23) was the first exponent of historical semantics to focus on semantic meaning in language, and highlighting on the psychological orientation of the study of meaning. Bréal (1897) claims that an adequate understanding of words in their contemporary meaning requires a thorough knowledge of their semantic history. He insists that: 'Only history can give to the words the degree of precision that we require to understand them adequately'. There are two aspects to words: the word as a structural unit and more specifically the word as a communicative act. With regard to the first feature, meanings are psychological cognitive entities, i.e., a kind of thought or idea: '(Le langage) objective de la pensée' (Language makes thought objective) (Note 24).

\subsection{Cognitive Semantics}

Cognition semantics is an approach in the field of psychology that emphasizes internal mental processing of language in order to understand the meaning of the words people use. It is interested in the psychological result of perception, learning and reasoning 'Principles of linguistic history by Hermann Paul. (1846-1921). Cognitive semantics views language use as an internal mental activity that involves the distinction between the 'usual' and the 'occasional' meaning of an expression. Here, the usual or literal meaning (described as usuelle Bedeutung) is the established meaning as shared by the members of a language community. 'Usual meaning', is the total representational content that is associated with a word used by any member of a speech community. By 'occasional meaning', we understand the representational content that an interlocutor associates with a word when he uses it, and which he expects the hearer to understand and associate. The occasional meaning (okkasionelle Bedeutung) involves the modulations that the usual meaning can undergo in actual speech ( Hermann Paul, 1920: 75). 
Within the same thought, linguistic philosophers held that words are performative acts used to achieve things. They argue that the function of language goes beyond mere form, pronunciation and spelling to convey deep-seated thoughts and the psychological state of the human mind. Austin (1962), for example, beliefs that speech acts or words are performative acts used to get things done in life. Thus, claim that words refer to, or name things. Linguistic philosophers held that if words are references to things without intending the word to be the thing, then language use enables man to express his unlimited amount of knowledge on an unlimited scale. Language and the concept of a word as a reference helps him organise his thoughts and classify things naturally. Cognitive semantics considers insights provided by the context is all-important to understand the semantic shift expressions make from usual to occasional meaning. In effect, the usual meaning involves not a selection of one meaning from among many existing ones, but the concrete specification of a more general sense. The word 'corn', for instance, used to be a cover term for all kinds of grain, but was differently specialized to 'wheat' in England, to 'oats' in Scotland, and to 'maize' in the United States, depending on the dominant variety of grain grown in each of these countries. The clearest criterion for a shift from the occasional to the usual level is the possibility of interpreting the new meaning independently. For the pragmatic specification, the essential idea is that context needs to be seen from a communicative point of view as meanings are dynamic processes not only in function of the (situational or social) context. The new perspective is not so much 'what are the structures of different words, and 'How are things named and classified through language?' but 'what do words mean?' 'How do words enable speakers to achieve things? This view can be extended to study the language of corruption in Cameroon. The word 'goat', for instance, is used as a cover term for all kinds of ruminant animals among Cameroonians. However, a goat may refer to a cow, or a sheep, though in the Cameroon context, some speakers metaphorically use it to hide the request for money or gifts as a bribe for fear that everyone might understand.

To sound courteous yet trickish, speakers resorted to rhetorics as a technique in public speaking, i.e., the arts or skill of using language in special ways to please and persuade people, developed as 'rhetorical tropes': ways of formulations that embellish a text to attract the attention of the audience with such figures of speech as euphemism and metaphor. Euphemism as the metaphor in language is the substitution of an inoffensive or less offensive word for one that might be unpleasant and hurting. In Latin, the word 'penis' for instance, originally meant 'tail', and the first meaning of vagina is 'sheath (of a sword)'; in both cases, a word with neutral associations is preferably used for a taboo-laden concept. Note that corruption is a taboo laden practice, condemned and punishable by the law, hence enacting this tabooed action requires discretion. Many language users do not directly shock, hurt, or tell listeners of their intention to shock, hurt or corrupt. It would be criminal. In most cases, speakers tend to be euphemistic and metaphorical. A metaphor is a kind of indirect comparison in which two unlike things are likened to each other without using comparatives as 'like' or 'an'. The metaphorical sense of a word creates an association between two dissimilar entities or ideas, and as a result, illuminate each other and deepen the meaning of both ideas. 


\section{Mll Macrothink}

International Journal of Linguistics

ISSN 1948-5425

2021, Vol. 13, No. 1

These concepts provide different perspectives of a communicative acts in a language. It explores the mechanisms of language and meaning using both critical discourse analysis and content analysis, touching on the Conversational analysis and theory of Relevance. For instance, in 'goat di chop place where dem tie ye', the speakers compares the person who receives a bribe to a goat and the bribe taken with eating grass. In this vein, the metaphor depends on a combination of a principal term (goat) the subject to a secondary term 'grass' advantage (favour-). The principal term conveys the concrete or literal meaning, and the secondary term is used figuratively to add abstract meaning, which may be confused by the listener. Nevertheless, such use adds vivacity and flavor to natural speech. In this other example, 'kolanuts' a common specie of nuts from a tropical plant growing in the west and northwest regions. Categories of words and utterances such as these and many others in the data collected for this study proved an excellent starting-point for lexico-semantics analysis. For example, when a speaker uses the word 'kolanuts', there are several layers of meanings that could be examined. At the level of semantics, 'kolanut' indicates a valuable economic fruit; the determiner shows that both speaker and hearer have previous knowledge of this fruit. Frequently consumed by mostly elderly person, these nuts are considered highly precious and valuable when offered to important personalities in African culture. 'kolanuts' symbolize the bonding of friendship. At the level of pragmatics, the hearer might infer that the word 'kolanut' is often associated within the context of proposal in traditional African marriage as a symbol of a bond, alliance, or vow to remain together as the different parts of a kolanut are stuck together, signifying allegiance, unity and power. It is a symbol of strength in unity.

The discussion concerning langue and parole was first suggested by Ferdinand de Saussure and popularized in his Courses in General Linguistics, collected by his students and published posthumously in 1916. Abandoning the mindset, goals and objectives of historical linguistics, Saussure advocated a synchronic examination of language. Not interested in studying a particular language or the linguistic habits of any one member of a given speech community, Saussure sought to examine language in general and to identify the systems or rules and conventions according to which language functions. Saussure's views on language influenced linguistics during the twentieth century, and his imprint can be found in theoretical works discussing phonetics, phonology, morphology, syntax, pragmatics and especially semantics. Saussure's (1916) later attempts to reconcile previous opinions saying that the knowledge speakers have of a language and what the speakers do with this knowledge in practice are distinct operations.

Indeed, the distinction between langue and parole forms an important part of the theoretical basis of structuralism. For Saussure, three aspects of language could be potential objects of consideration in linguistic study, and he used the French words langage, langue and parole to designate these aspects. Langage refers to the anatomical ability and psychological need or urge of humans to create a system of linguistic signs for expressing ideas. Langue represents a system of rules, usages, meanings and structures that are products of the human ability to create language and are shared by members of a specific speech community. Parole is often equated with speech. It is the concrete realisation of a collectively-internalised system and also reflects the personality, creativity and physiological capabilities of an individual speaker. 
Understanding this, he focuses on two systematic principles of language, namely; 'langue' and 'parole.' Referring to these two aspects of language expounded by Ferdinand de Saussure at the beginning of the twentieth century, langue denotes a system of internalized, shared rules governing a national language's vocabulary, grammar, and sound system; parole designates actual oral and written communication by a member or members of a particular speech community. Overall, Saussure paid little attention to langage, considering it the subject matter of other fields of inquiry, and he regarded parole as too idiosyncratic. Instead, he believed that linguistics should study langue in order to gain a picture of the comprehensive, complex, ordered assemblage of sounds, words and their syntactical units. Making use of a concept suggested in the writings of the French sociologist and philosopher Émile Durkheim, Saussure viewed language as a social fact. According to Saussure, language is acquired through the socialisation process; it is not created through a speaker's ingenuity or experimentation. Moreover, he felt that an individual's potential influence on language is minimal. An individual might create a memorable turn of phrase, but that person is unable to affect the overall structure or sound system of a given language. Finally, speakers can manipulate language in minor ways, but language imposes its rules, order and possibilities on all speakers without exception.

As part of their intuitive knowledge of langue, members of a speech community share possession and comprehension of a body of signs (signes). According to Saussure, a sign consists of two components: a signifier (signifiant) and a signified (signifié). Linguistic signs can encompass words, units of grammar, and expressions. The signifier is a sound or series of sounds, and the signified is the meaning that the sounds represent. Saussure was careful to note that signs are actually linked to clusters of meanings or associations and not to specific things. For example, the word 'house' does not refer to a specific object in the world but rather to a concept involving images and associations that speakers have in mind when they say or write the word. Furthermore, the connection between the series of sounds and the cluster of images and emotions is arbitrary. The words 'girl', 'Mädchen', and 'niña' might all refer to a female child, but there is no direct connection between the sounds of each word and the meaning. Even so, speakers form a strong connection in their minds between sounds and meaning.

Saussure stated that langage, the psychological and physiological faculty to produce meaningful acts, does not manifest itself solely in the creation of individual sounds, words or units of meaning, and he stressed that parole, individual communication within a speech community, does not take on the form of a string of unrelated utterances. Langage becomes a reality in langue - and ultimately in parole - through the rules governing the use and organisation of signs. These linguistic conventions are expressed in the form of syntagmatic and paradigmatic rules, two types of systems that enable language to convey messages by organising and sequencing the building blocks of sound and meaning. Syntagmatic relationships refer to the limitations governing sequences of sounds, parts of words, and complete words offered by a given national language to create meaning. However, paradigmatic relationships concern the existence of words of similar meaning or grammatical form that can substitute for each other in a given context. 
Saussure's views concerning langue and parole, as well as his understanding of the purpose and goals of linguistics, have exerted immense influence on linguists in Europe and North America. Leonard Bloomfield, Franz Boas and Edward Sapir adopted Saussure's method of objective, synchronic language study as the basis for their descriptive analyses of various North American Indian languages. Bloomfield also incorporated elements of Saussure's innovative teachings into his writings, most notably Language (1933). Roman Jakobson and other members of the Prague School of Linguistics were inspired by Saussure as they investigated sound systems and developed theories of phonetics and phonology. On occasion, agreement or disagreement with Saussure's beliefs can be traced back to an individual's political and philosophical leanings. The Marxist linguist Mikhail Bakhtin disapproved of Saussure's efforts to distinguish individual production of language (parole) from collective knowledge and linguistic awareness (langue), a division that, to Bakhtin's way of thinking, isolates an individual from society; he was much more in favour of a theory of language that portrays speech as dependent on, and a product of, a specific social context. Stimulated by Saussure's discussion of the sign and its two components - the signified and the signifier Roland Barthes investigated the contrast between the message of our speech and its form and articulation, and Kenneth Pike advanced his system of tagmemics, a type of grammatical analysis developed in the 1950s. Noam Chomsky, too, responded to Saussure's ideas when he transformed Saussure's concepts of langage, langue and parole into 'language capacity', 'competence' and 'performance', and achieved a new understanding of the Saussurean concepts. Twenty-first-century linguists remain attracted to Saussure's concept of the dual nature of language and to his theory of meaning.

\subsection{Conversational Discourse}

Conversational discourse, rooted in the writings of H. P. Grice (1975), claims that conversation proceeds according to basic interactional principles acquired, observed, and applied by all human beings in the conduct and organization of everyday social life. Grice (1975) asserts that human beings follow a behavioural dictum in conversation called the Co-operative Principle. It is based on the assertion that each speech community has its unique ways of speaking and social behaviour. Social interaction is based on certain maxims referred to as the co-operative principle. To this effect, Grice $(1975,1989)$ describes two conversational maxims, namely; the Co-operative Principle and Politeness Principle, and he asserts that these maxims render social behaviour and people's attitudes acceptable or unacceptable. The assumption is that conversation activity runs smoothly and successfully because the participants follow these two maxims. These two maxims guide the fundamental idea of conversational principles as appropriate social behaviour. However, when listeners expect speakers to say what is truthful and sincere, but what they get is untrustworthy and obscure, the speaker intends to hide the truth and would use language that is corrupt and full sloven speech.

\subsubsection{The Co-operative and Politeness Principle}

According to the Co-operative Principle (Grice, 1975), human beings follow a behavioural dictum, which aims at a mutual understanding between participants in social interaction. 


\section{Macrothink}

International Journal of Linguistics

ISSN 1948-5425

2021, Vol. 13, No. 1

Conversationalists have to be cooperative polite, and sincere in their exchange deals. Conversationalists observe this in order to be rationally cooperative in their actions and acceptable in their social behaviour. Describing verbal communication, Grice (1975) argues that talk is characterized by the exchange of ideas and feelings in a co-operative effort. Briefly, verbal interaction operates more smoothly and successful when the participants co-operate in taking turns, starting with initiation, followed by a response and a feedback I-R-F. This verbal interaction is characterized by questions and answers in which one speaker creates discourse with the listener (s) in mind, trying to understand how he reacts to what is said. The reaction of the listener helps him to adjust and re-adapt his speech as it unfolds, and indeed, his social behaviour as a whole. Based on this Grice's (1975) basic 'Conversational maxim,' the principle states that:

Make your conversational contribution such as is required, at the stage at which it occurs, by the accepted purpose or direction of the talk exchange in which one is engaged. (Grice 1975: 45)

In this formulation, he claims that conversationalists should make their contribution as required, relevant and acceptable. However, when a speaker does not say what is truthful and sincere, his language is corruption, obscure and full of utterances that hide the truth and do not mean what is said. Grice (1975) has developed the co-operative principle into nine maxims classified into four categories as: Quality, Quantity, Manner, and Relation. In order words, people who engage in verbal interaction tend to interpret language on the assumption that its participants obey any or all of these four maxims:

- Quality: Try to make your contribution truthful and sincere.

1) Do not say what you believe to be false.

2) Do not say that for which you lack adequate evidence.

- Quantity: 1) Try to make your contribution as informative as is required

(for the current purposes of the exchange).

2) Do not make your contribution more informative than is required.

- Manner: Be perspicuous.

1) Avoid obscurity of expression.

2) Avoid ambiguity.

3) Be brief.

4) Be orderly.

- Relation: Be relevant.

(Grice 1975: 45-46) 
According to the maxim of quality, Grice (1975) believes that in conversation, participants must make their contribution as truthful and sincere as possible, but the words and expressions used in corruption are neither truthful nor sincere, and say what they believe to be false, yet assume that people adhere to the Co-operative Principle. Furthermore, the words used in corruption are not as informative as is required and can be considered obscure and ambiguous. Though Grice's conversational maxims can be usefully applied to a number of problematic issues in the interpretation of conversational behaviour, following these principles alone would never account for what participants say and do in the practice of corruption. Grice's (1975) conversation maxims provide possible explanations for the otherwise puzzling interactional behaviour, but conversational analysts and discourse analysts felt that these maxims can handle only some aspects of language use. The analysis of 'kolanut' from this perspective cannot be understood successfully though participants within this community share a certain cultural knowledge concerning 'kolanut.' Here, the analyst needs to apply a socio-pragmatic approach, which examines the lexical unit in its context of use.

Where the maxim of quality requires speakers to be truthful and not to say what you believe to be false, nor say that for which there is lack of adequate evidence, the "Quantity" maxim states that speakers should also be as informative as is required, and make their contribution more informative than is required. Neither to give too little information as in 'shake skin', or 'fix me', or too much as in 'goat di chop for place where dem tie ye'. Similarly, in making a brief and precise statement 'Shake skin', the listener may be expected to shake his body since the information is not explicit enough. He feels that to give more information than the hearer needs may betray his intentions. This explains why the corpus is made up of short brief texts so as to provide just the encrypted information: for example, 'fix me', is short, brief and intentional. Nevertheless, he does not follow the maxim of 'manner', i.e., the necessity to be more explicit to show sincerity. In most examples, speakers avoid saying much yet producing ambiguous utterances. In an attempt to hide his intention, the speaker uses a pidgin proverb; 'goat di chop for place wey de tie ye' to justify his corrupt action. Note the emphasis on 'goat' and 'chop' metaphorically substituting himself to a 'goat'. He gives the impression that this is a widely known and accepted practice in case the listener doubts it, he may verify from the others. This important caveat to Grice's maxim of 'Quality' considers that speakers ought to tell the truth, for telling a lie or hiding the truth is an aberration, and violating the maxim of truthfulness is frowned upon in a society where corruption abounds. The third principle is that of 'Relation' or 'Relevance', which holds that what is said is relevant to that which has been said before, and what will follow. Notice, for example, that saying ' $0 \%$ corruption' is a wish for corruption to be eradicated completely in Cameroon. It is irrelevant to justify a social and culturally acknowledged misnomer as corruption.

Grice's fourth maxim is that of 'Manner', which states that speaker's need to be brief and orderly, and avoid obscurity and ambiguity in the information content provided. In the corruption discourse, for example, [1, 2, 3, 12,], speaker's produce short, brief utterances in an effort to be obscure, note that 'goat' is ambiguous, and secondly notice the overuse of the lexis, 'somethin', which does not precise his request to help the listener establish a coherence between what is requested. The utterance is incoherent, vague and meaningless. However, it 
is a coded act of corruption referring to an object known only to both speaker and listener. Notice here that the utterances in $[1,2,3,4,5,6,7,8$, etc., $]$ focus on a request for bribe and partaking in corruption. The maxim of 'manner' is flouted with in many instances of corruption, which requires that the speaker 'be perspicuous' and 'avoid obscurity' of expression. It is also assumed that a speaker packages what he intends to say in a way that is appropriate, and says as much as the listener needs; and makes what he says relevant to the purpose of the talk; and will try to say it clearly.

There is need for an approach which accounts for what speakers ought to do and not what they actually do with language and their implicit meaning. The meaning conveyed by the speaker and recovered by the hearers' inferences is known as 'conversational implicature.' An analysis of real conversational interaction demonstrates that communicators presumably abide by the four interactional rules summarized as:

i- Informativeness (be adequately informative)

ii-Truthfulness (make contributions which are true)

iii-Relevance (make contribution which are relevant).

iv-Style (be brief and clear).

(Grice 1975: 44)

However, Grice (1975) notes several other instances where speakers fail to comply with some of these maxims. Telling a lie, being untruthful, exaggerating speech, or speaking metaphorically to someone, for instance, is violating the maxim of Quality. The observation is that as far as conversation is concerned, most speaker's value the maxim of 'Quality' much more highly than the other maxims, and as Grice (1975) notes, violating one amounts to a moral offence, whereas violating the others is at worst inconsiderate or rudeness in instances of corruption. The analysis has been carried out with these various frameworks in mind as each theory contributes to throw more light on the concept of language use in context.

\section{Analytical Units}

Firth (1951) emphasized that meaning is a property of all types of language patterning; whether words, word-groups, phrases or sentences and that one cannot describe language forms without appealing to syntax and meaning.

In its broadest sense, lexical semantics examines the stock of words (the lexicon) in a given language, i.e., content words or lexical items" as communicative units of analysis. Halliday et al., 2004) noted that [T]eachers of English have customarily distinguished between function or content words, like snow and mountain, and grammatical words, like it and on and of and the .... According to Halliday et al (2004), a language is not just a system of systems but there is meaning used for communication. It includes verbal, non-verbal, written or visual, that is, meaning is conveyed by the total speech act. For instance, utterances such as 'kolanut', tchoko', "goat di chop for place where dem tie ye" / 'A goat eats where it is tied,' for example, are frequently heard in Cameroon. 


\section{Mll Macrothink}

International Journal of Linguistics

ISSN 1948-5425

2021, Vol. 13, No. 1

The units of analysis here are both complete independent and incomplete lexical units including "words, utterances, phrasal structures" considered as "logos" - to denote "learning and concerned with knowledge. Literally, lexicology is the science that studies words from the smallest meaningful units as speech acts to larger stretches of a language. From this perspective, a word is composed of one or more morphemes, each made up of one or more spoken sound units. Syntactically, morphemes are incomplete meaningful units that cannot be used independently. They are always parts of words, whereas words can be used as complete independent meaningful units. This view of language defines linguistic forms as ideational. Note that in the example goat di chop for place where dem tie ye" / "A goat eats where it is tied,' the imagery is a metaphor, and the listener might hardly pay attention to what the speaker means by the 'goat' is attached to its benefits. Notice that, pragmatically, a 'goat' in Wimbumland is considered a lustful animal and noted for its appetite. To qualify someone as a goat entails describing him as lascivious and emotionally uncontrollable. Theories described above and related to the study of speech act and conversational analysis are capable of eliciting meaning in simple single forms of a word as well as word groups, which exist in the language as a ready-made unit. These units of analysis tie in with the notion of a communicative act considered as a 'unitary whole' and well-formed structural features evident in a supra-sentential stretch of language, coherent and meaningful to language users. Each speech act used is consists of a text, considered as the sum of those linguistic and social features of a text, distinct from its structure. Texture, whether spoken or written, refers to any structured sequence of linguistic expression, which together, forms a 'unitary whole' or text Halliday et al. (1976: p.2).

On observation, the preceding data demonstrates that the words, utterances, and lexical structures frequently encountered in this register exhibit relational properties of synonymy, polysemy, euphemism, metaphor, borrowings, coinage and proverbial. The following section presents an analysis of the linguistic corpus of corruption. Column 1 presents the sample data; i.e., words, compound words and lexical phrases referred to as metaphoric use; column 2 presents the literal sense and column 3 the metaphorical interpretation.

\subsection{Lexico-Semantic Structures}

Sample data Literal sense

[1] Tchoko

[2]Makala paati
A tip, commission or small reward for a service rendered.

A variety of small puff balls made locally from beans or flour known as makala or Makara.
Metaphorical Interpretation

Usually in the form of money given as payment for a service rendered. .

Money or food/drinks shared by someone holding a high public office to win over sympathy and favour for favour especially votes. This form is mostly used in French speaking areas.

[3]Backdoor A door found at the rear part of the house. A secret Unofficial secret deal, involving exchange of 
entrance/exit.

[4] Beer

[6]Envelope

[7]Godfather

To wrap or to conceal or obscure from sight or understanding.

An originator or leading exponent, usually a male godparent from the head of a Mafia family or other organised

[8] How? criminal gang.

(Adv.) informal greeting form to [9] K\% rule [10] $30 \%$

[11] Kola

An alcoholic drink brewed from malt, hops, or corn by fermentation.

Used to describe old vehicles used for public transportation without legal authorisation.

find out how the person is doing.

An informal acronym representing a certain percentage as commission.

An informally created acronym designed to represent a certain percentage to be retained during payment.

A tropical African comestible fruit whose seed contains caffeine and bromine, used for
Secret and concealed, often for illicit reasons to buy their passage way in the transport sector. Tips given to police.

Designates a secret deal, sealed and package as facilitation payment, exchange of money to influence decision or favour.

Often used within Christianity to designate someone in high position of influence, and power to manipulate others for personal gains. This includes ministers, directors, Mps etc. traditional marriage rites. It is
An informal greeting form used to indirectly request for motivation. Co-variants include 'something' or 'talk well.',

An undefined imposed amount of money deduced as commission rate as transaction fee etc. It seems to be an institutionalised rule.

A specific interest rate as commission retained in payment for a service rendered. (See co-variants; $15 \%$ or $10 \%$ etc.) 
Somethin sold and chewed mostly by An incentive or stimulant requested as elderly people.

[13]

chase files
An unspecified or unknown thing or amount requested. advance payment for a service rendered. In African tradition, this fruit is a symbol of friendship, unity, love, and life. In this context it is used to stimulant to request for payment for services rendered or to be.
The act of pursuing something in an effort to overtake or capture, run after; to drive.
An outright request for an unspecified offer or money for a document to be treated for onward transmission from one office to another. It is considered an incentive or stimulant.

An unspecified tip or thing as money, a gift, or a present given to motivate or facilitate the treatment of files.

5.2 Word Groups or Phrasal Structures

\begin{tabular}{ll}
\hline $\begin{array}{l}\text { Sample } \\
\text { data }\end{array}$ & Literal sense \\
\hline $\begin{array}{l}\text { [14]Push } \\
\text { file \& }\end{array}$ & $\begin{array}{l}\text { To push is to exert force over } \\
\text { something in inertia, to force to } \\
\text { move. }\end{array}$ \\
$\begin{array}{l}\text { [15]Follo } \\
\text { w up }\end{array}$ & $\begin{array}{l}\text { To follow or run after a file } \\
\text { persistently, to chase or to pursue }\end{array}$ \\
& \\
[16] & $\begin{array}{l}\text { A volatile flammable mixture of } \\
\text { hydrocarbons (hexane and } \\
\text { heptane and octane etc.) from } \\
\text { petroleum; can be consumed to } \\
\text { produce energy. }\end{array}$
\end{tabular}

Metaphoric Interpretation

[17]Do

Designates something to fuel the system in the form of money as tip in order that document is treated; (see motivation, push), or act in a certain way, (money) payment before a service is rendered.

something To carry out an unspecified, unnamed action.

Give an unspecified amount of money or accept a proposition to render a favour for a post or some personal gain.

[18] Soya is the product from finely

Give a gift or receive this grilled meat as 
Eat Soya sliced and grilled meat mixed with money to to influence one's opinion, or receive spices and sold in front of a favour or promises. In politics, abandon one

[19]

Bought over

[20]

Change camps/

[21]Cross carpet

[22] for

taxi

[23]Fix

me

[24]Settle

[25]Oil the mouth

[26] Rub ma mob

[27]Say something [28] drinking spots enjoyed by many. one's opinion, acquire a new status by accepting promises;

To move over to the other side; To move or go across to the other side or interchange.

Money to facilitate movement.

\begin{abstract}
To get on board a taxi, one needs
\end{abstract} to pay the fare.

To repair, amend, put things in place; To finalise, arrange, fix, pay off, To establish oneself, ,

Exert pressure on the mouth, oil the mouth in Pidgin English or put oil on or wet the lips.

To make things run smoothly/ Exert pressure on the mouth

To make a statement, be articulate. To express a personal idea about something. Exert pressure on the mouth, To wet of lubricate, smear.
Use money to influence, change party to join the opposition or vis versa through pressure and for a reward in return (see decamp)

Use money to accept a proposition or get a favour for a position or personal gain. To convince someone to change his opinion. Use of money or gift to receive favour or promises.

In politics, to abandon one party and join the opposing party through pressure and for a post or reward of any kind in return (see decamp). Money or promises used to influence someone abandon one's party to join the opposition.

-Money given as incentive, stimulant to request for a favour in return for a service.

Request, ask for motivation for a service to be rendered before or afterwards, to put certain things in place.

A request to make an effort and pay off a debt. Give money see 'say something') To pay an outstanding charge as favour.

To motivate, give a bribe (usually in the form

of money (induce, motivate someone to render a service. (see "say something". "Talk well")

Induce someone to motivate or pay some money or something in return for a service.

Induce someone to motivate or pay some money or something in return for a service.

Speak or Come out clearly. 


\section{Talk well To express one's thoughts, feelings, or desires freely, by means of words.}

[29] Make a gest

Do something to render the speaker happy. Make someone feel happy

[30]

Shake

skin

[31] Make me hear fine
Move the body

Perform an act to make the requester happy
[32]Goats and fowls

[33]Goat

di chop

for place

where

dem tie ye

[34]

Crash ma

bak a

crash ya Pidgin proverb. what you do to bak others will be done to you. Do good to someone to receive good.

[35]

Mouiller Wet the mouth.

Domestic animals reared, consumed as food or sold for a living. Domestic birds as fowls and goat (Capra aegagrus hircus) any of numerous agile ruminants related to sheep but having a beard and straight horns.

A goat eats the grass around where it is tied

\section{la barbe}

Offer huge sums of money (well) or valuable gift in return for a service. An indirect request for the hearer to give something, money in return for a service as bribe (see "beer").

An indirect request for the hearer to give something, money in return for a service as bribe (see "beer").

Provide the speaker with what can make him or her happy. This can be in cash or kind, as request for a favour.

Food often prepared and consumed as soya or in chicken parlours. Here, a goat and/or fowl is given in exchange to influence a service. Commonly heard in private and public services as bribe for a favour of position, employment etc. /

Pidgin proverb to echo that one is attached to where there are many advantages.

The back is a part of the body not easily accessible to the owner, so he needs someone else to help. Drawn from this register it is used to denote a lubricant or grease. Used to express desire or need for something.

Give a person something to lubricate the process. Used to designate the act to motivate someone to act in a way to favour the giver, facilitate the progress, note that public service workers are compared to a goat, who eats from where he works. 


Sample Literal sense $\quad$ Metaphoric Interpretation
data

[36] Wet your jersey

Mouiller le maillot

[37]Gombo

It is a common slimmy vegetable soup mixture, the main ingredient being Okra, or okro plant which grows in tropical Africa and consumed as sauce with garri or water fufu especially in most West African countries.

[38] Ma bière

[39] Suivre A beer is an alcoholic drink brewed from malt, sugar, hops, or corn and water and fermented with yeast and high alcohol content.

les dossiers

To chase documents,

[40]

Arroser

[41]Faire quelque

chose

Pour water on plants or refresh

To do something.

\section{[42] Parle}

bien

Speak well

\section{[43] C'est} comment?
Express the idea that when someone has to do you a favour, It is a request for a bribe (money).

Money or envelope received mostly by media professionals. Variants gombology, (Also see makala).

Stimulate or compel the receiver to act in favour of his client

Facilitation payment for favour of his client. To give a bribe (money) activate the process. Co-variants: follow up, Push etc. -

Induced request to give something, money or gift.

Request for an unspecified amount or receive money as an advantage of a person's social position or political office to give or receive money or tips. 
[44] On How are you? (Greetings.)

fait

comment?

[45] et moi

What can we do

alors ?

[46] Pour

joindre les

deux bouts

And what about me?

[47]L'eau

To make both ends meet

[48] il faut

bien parler

Water

Speak well.
Stimulate someone to make a commitment of expected collaboration.

An indirect request for to reconsider a position. Indirect request for unspecified amount of money without fear

An rhetoric indirect request for a bribe, unspecified amount of money without fear

What do I gain?

Stimulate someone to do likewise, expecting collaboration. i.e. if you give me, I will give you too (see" chop a chop")

An indirect request for assistance in any form, tip or present

Used to designate something that is the source of life and hope. It quenches thirst for something.

Pushing the listener to act in a certain manner

\section{Reference and Sense}

A reference is a sign or remark that calls the listener's attention to something or some situation or event that contains an important comment, input, statement, message, content or subject matter. Generally, it is an indicator that is designed to orient the listener. In this light, [9]. ' $\mathrm{k} \%$ ', [10] ' $30 \%$ ' consists of remarks that draw the listener's attention to the concept of [12] 'somethin' [17] unnamed but related to corruption and $30 \%$ to a certain amount of money evaluated in terms of percentage. Similarly, extract $[18,19,20,21]$ use the words 'eat soya', 'bought over', camps', and 'carpet' to refer to the same concept of moving to a new side expressed in the verbs 'change' or cross', which consists the a source of information in the infinitive form in the same way that the translation of 'chaise' (Fr) into the English word 'chair' might denote both chair, bench and stool, or there might be two words corresponding 
to different types of chair to refer to a seat for one person, with a support for the back. Moreover, different words or phrases may designate one concept with distinct senses pointing to the same concept in the world of corruption, for example, [8] 'How', [9] ' $\mathrm{K} \%$, and [10] ' $30 \%$ ', [12] 'somethin' refer to the same idea of deliberate retention of an agreed percentage as commission for the deal, though each may carry different values. In this data, the expressions [49] 'DG', [33] 'Goats and fowls' and [34]'Goat di chop fo place where dem tie ye' make reference to animals as 'goats' and 'fowls,' including any agile but tasteful ruminants domesticated for food, and here used to cloth corruption. The metaphor ' $D G$ ' refers to grilled spicy chicken prepared, highly seasoned with spices and pepper and eaten with some fried plantains, 'baton' or Irish potato chips and sold in beer parlours. Thus, the word 'goat', also reminds one of goat meat as a reference to the meat from a goat, though bush meat is a general term for grilled antelopes, buffalos, porcupines, bush cats etc., hunted and dried by hunters. Bush fowl is another term used to refer to a species of birds living in the bush known as partridge, but not all fowls in the bush are bush fowls. In the situation of corruption, the word 'goat', 'fowl' are signifiers making reference to the object in the real world. Metaphorically, the word 'goat' or 'fowl' signifies motivation, bribe, facilitation payment, incentive offered to influence a service to be rendered. In contrast to reference, the sense of a word is its meaning in relation to the linguistic system of which it is a part, and this meaning is internal and shared by its speakers. From a pragmatic perspective, the meaning of 'goat' relates to other animals like cows, fowls, and object, money, etc., as bribe in the semantic field. 'Language is a translation of reality, a transposition in which particular objects only appear through the intermediary of the generalizing and classificatory efforts of thought' Bréal (1897: 275). Translational equivalents of words are rarely completely accurate because the precise set of things a word can denote varies from context to context, in part due to this relational aspect of sense and meaning. Thus, language use has to do with reality and categorization: it stores cognitive categories and pops up when human beings attempt to make sense of the world: Language, then, is not autonomous; it is linked with the total set of cognitive capacities that enable man to understand the world with ever more refined conceptual tools embedded in his perception of the world.

In a nutshell, the sense of a word deals with the meaning of the word or expression; the way in which the speaker perceives a situation and interprets it. The sense is the faculty through which the external world of reality is apprehended and categorised. Different words or phrases with distinct senses can point to the same semantic concepts in the world. We noticed above that 'Theo', 'Nyu', 'Tai', 'Allah', Dieu', 'The I am that I am,' all refer to one and the same person God', carrying the same meaning. For example, texts [27], [28], [29], and [30], use the active dynamic verbs 'say', talk', make', and 'shake' as well as [41], [42] technically with the same semantic references, yet with different shades of subtle meaning with 'somethin', 'well', 'make me hear fine' 'shake skin' as synonyms. Since words are easily accessible, discrete and small units of language, a lot of efforts goes into defining words, or, if possible, "prescribing" meaning as few words have a direct, original "natural" significance.

In Saussurean theory of the sign, the signification encapsulates the signifier (the sound image-word) and the signified (the concept). Saussure distinguishes between the signifier and 
signified and stressed that the relationship between the signifier and the signified is conventional and arbitrary, and that both terms are psychological in nature. Look at the words 'tree' and 'plant,' where a tree signifies a plant though a plant does not of necessity mean a tree. The sound image "tree" may refer to different kinds of trees or it may even be a metaphor for forest. In certain cases, there is no one-to-one relation between the signifier, 'say', 'talk', make', and 'shake' and the signified corruption. The most fundamental concept is that the word as the basic unit of signification comprises of both a mental image (signifier) and an idea (signified), independent of its meaning. Meaning depends on usage within a (conventionalized) system of language.

\section{Synonyms and Polysemy}

A synonym is a word, morpheme or phrase that means exactly or nearly the same as another word, morpheme or phrase in the same language such as the English words, begin, start, commence, introduce, initiate that appear as synonyms. Synonymy deals with the relation between two lexical items having different forms but expressing the same or a seemingly close in meaning. Other examples are 'author/writer', 'fate/destiny', and equally 'mouillir la barbe'/oil my mouth'/grease the mouth. Synonyms are words with different spellings but with the same, or approximately the same meaning. While this is a well-known concept, taught to schoolchildren from a young age, it is rare that two lexical items can be truly identical and interchangeable.

The Greek word, polysemy means multitude but related meanings. In other words, even though they may have the same spelling, yet different and related meanings. The data analysed contains instances of polysemy as words or phrase with two or more related meanings. The word "bank", for example, can refer to; a financial institution; the building in which such an institution is located; a part of the river or beach; "to rely on." In a similar way, other examples recorded include the word 'kolanut', which is a tropical fruit valued as an economic product, but also an indispensable item of the brides-wealth in traditional marriage; it is also a symbol of bonding, unity and strength in some traditions. The seeming difference between reference and sense is useful here, as more often, supposed synonyms often assume two separate senses with a common referent. Pairs such as the nouns peace and calm, the verbs enjoy and like, and the adjectives funny and humorous, can be substituted in some contexts and not others, as word choice is often contextually conditioned. On closer inspection, most words are polysemic, and that each sense of the word has different synonyms as evidenced in the analysis of the data. Apparent synonyms stand apart when polysemy is manipulated; for example, while big and large, little and small are often given as classic synonyms, a big sister is not the same as a large sister (Saeed 2016, p. 62). In the present corpus, synonyms are sometimes differentiated by dialect or register: for example, the choice of [25] 'oil my mouth', (Eng.) and grease my mouth, (Eng.), [26] 'rub ma mouth' (CPE) and [36] 'mouillir la barbe' (Fr.) (wet the beards) do carry related meaning which suggest regional dialectal associations, but are not easily interchangeable.

Lexical semantics accounts for different aspects of meaning depending on the situation in which language is used. Meaning is related to with the extra-linguistic environment, though 
this need not imply that the meaning of a term is the object for which it stands. For example, morning star and evening star. By any reasonable standards, these two terms have different meanings, though today we are convinced that they both refer equally to the same astronomical object, the star. To conclude from such an obvious case that extra-linguistic phenomena are not crucial when distinguishing one set of meaning from another set is absurd, for 'morning star' and 'evening star' differ precisely in the extra-linguistic occasions on which they appear: one for a bright movable object in the sky seen shortly before dawn in the morning, and the other seen shortly after sunset in the night or evening. If the meaning of a word consists of the extra-linguistic criteria by which we determine its appropriateness on a given occasion, then the 'morning star'-'evening star' distinction need cause no problem even to linguistic philosophers who worry. Meaning do not exists, ready-made, in the language itself; they are worked out. The syntactic structure provide linguistic clues to what propositions are expressed and what illocutionary acts are performed. On the basis of these clues we make sense of the utterances. What speakers do in producing corruption discourse of this type is not to provide as many clues as necessary for the satisfactory conveyance of meanings. People hardly do express everything they know. Indeed, it is probably impossible to do so. The point is speakers inevitably rely on commonly shared knowledge, and listeners make assumptions about what the person we are addressing can infer from what we say.

Trier's (1930), semantic field theory suggests that a group of words with interrelated meanings can be categorized under a larger conceptual domain, known as a semantic field. For example, the expressions [4] beer, [18] 'Eat Soya', [33] 'Goats and fowls,' and [32] 'Goat di chop fo place where dem tie ye,' and [49] 'DG', fall under the larger semantic category of food and drinks. Semantic field theory asserts that lexical meaning cannot be fully understood by looking at a word in isolation. Semantic relations describe any relationship in meaning between lexemes, where the term meaning refers to the various ways in which language is tied to the world and not to some single limited aspect of that relationship, such as naming, informant response, or the like. Socio-pragmatics is concerned with three aspects; the language, the world, and (most particularly) the relationship between the language someone uses and the society in which he lives. Take, for example, the words 'Kolanut', 'bitter kola'. Everyone knows these tropical fruits and what they look like. However, these fruits have various significance in different cultures linked to their history. kolanut is a symbol of unity and strength among the Wimbum. It is commonly believed that he who brings kola, brings life. Most words, however, correspond not to things or points in space-time, but to concepts.

Because of synonyms or polysemy, any set of reference rules will still leave many points optional, though they greatly reduce the degree of optionality left by the grammatical rules. Rules of reference distinguish between mother and father, but (in most conventional analyses of kinship terminology, at least) father, daddy, papa, including uncle, (from a cultural perspective) are left as synonyms, which is to say that the choice among them is referentially optional. Clearly father, daddy, and papa or uncle are not identical, even though they all refer to the male parent. Note that in Wimbum tradition, a young maid's father is the uncle. The choice among these forms is governed not by the referent to which they all equally refer but 
by such factors as the speaker's personality, his personal feelings toward his father, and the formality of the situation.

Since concepts reside in the mind of speakers, it is easy for two people to have slightly different ideas about the same word as in the case of corruption. The expression l' eau' might be translated as water, but it does not define whether it is clean, dirty, hot, or cold water. Within the education circles in Cameroon, it signifies examination question leakage. Such cases question the validity of the etymological and conventional concepts of words and meaning. Knowing a language is often taken to mean having competent knowledge of the correct usage. A knowledge of use must of necessity include a knowledge of usage, but the reverse is not the case. Both the manifestation of the language system as usage and its realisation as use have meaning but the meaning is of a different kind in each case. Words have meaning because they are part of the language system and this meaning is recorded in their subconscious. Meaning may be arbitrary, and language does not merely reflect the world, but also creates and reconstitutes it. Interest in the connection between language use, speaker and society is a unified field and a self-sufficient system experienced in language as a 'Gestalteinheit.'

\section{Corruption as a Linguistic Metaphor}

Corruption has been considered as the violation, misuse or abuse of entrusted official position or title for personal and private gains either on an individual or collective basis, at the expense of the public in violation of established rules and ethical considerations. While Ofoeze (2004, p. 20) defines corruption as any action or inaction of any person, or group (public or private) deliberately perpetrated to secure advantages for oneself, a relation, associate or group(s) in a manner that detracts from the accepted regulations, morals, and/or ethical standards constitute a travesty of justice, equity and fair play. Lipset and Lenz (2000) on their part, considers it as 'any effort to secure wealth or power through illegal means, private gain at public expense, or misuse of public power for private benefit" (Lipset and Lenz, 2000, p. 112).

The data comprises of typical utterances which relate to the misuse or abuse of entrusted power categorised under as request for corruption, facilitation payments and influence peddling etc. Note that corruption [8], [25], [26],[37]; [38] involves the intentional offering, promise of giving or receiving undue pecuniary advantages to an official or decision maker in relation to the performance of their duties. Other examples abound, [9], [10], [44], [45] as a form of bribe paid to a person of influence within an organisation, in return for them securing some kind of benefit from their organisation for the person making the payment. Commonly, sample data [9], [10] are paid by companies seeking to secure profitable or favourable contract terms. The rates may vary from $5 \%, 10 \%, 15 \%, 20 \%$, to $30 \%$ commonly heard within the customs, public treasury and ministry of Finance. The amount to be deducted is determined by their social relationship. With secret commissions [3], [6], [12], [33], [34], companies often use agents to enter into contracts on their behalf, for example, to make purchase or sales in an overseas market. Secret commissions are a form of bribery whereby an agent requests for or accepts a payment to influence these contracts for the benefit of the 
payer, without the knowledge or consent of the benefactor. Conversely, speakers also use complex pidgin English structures like "crash ma bak a crash ya bak" or chop a chop, drawing their meaning from the local images and the environment of corruption. The P.E. compound word 'to crash' (scratch) in standard English, for instance, means to stimulate or to excite, and ' $b a k$ ' symbolizes that part of the body which is not easily seen from the front. In the context of corruption, this pidgin expression can be interpreted as "one good turn deserves another,' idiomatic expressions have assumed new connotations when used within the context of corruption. From such examples then, one notices that the concept of democracy is no longer one of freedom to choose but to push or motivate the person. This may be to secure a contract, to gain favourable terms, or even to prevent a contract being entered into with a competitor. Sample data of facilitation payments include [12], [13], [14], [15], [28], [32], often engaged in by a business to a government official in order to ensure that the entrusted official performs his or her normal corrupt duties for personal gains. In the public service ministries, for example, it is common practice to request for bribe by talking of 'chasing files', follow-up or push files' for documents or retirement benefits to be processed. The word 'chase', or in old French 'chasier' and English 'chaser', signifies to pursue, take, or to follow an object intently with the aim to capture it. A synonym of to chase is to pursue, to seek, and to chase a file describes the act of following-up a document till it's finality. In the context of corruption, to 'chase' a file means to obtain the required signature by offering a motivation that makes the documents to move from one office to another. Besides, note the use of imperative forms;' talk.., 'chase...,' shake...', 'say..., fix..., follow-up used are restricted to the simple present tense. Note that the verb 'do' in 'do something' makes the imperative form more persuasive and insistent. In fact, to "chase files", for reclassification, or advancement, one has to bribe, "grease or oil the mouth" or "mouiller la barbe' for personal gains. Metaphorically, it assumes a specific meaning commonly associated with the act of public service corruption. Other examples like 'tchoko' 'kola', somethin' etc., suggestive of motivation or money are associated with tax collectors, policemen, gendarmes. 'Do something' is a strong request to act.

Facilitation payments influence the behaviour of an official. Influence peddling [19, 20, 21], [28-32], also known as "trading" or influence "trafficking", with middlemen occurs where an official seeks to obtain payment in return for using their influence to secure an undue advantage or favour for the payer. Political events in Cameroon have given rise to makalapaati or eat soya. Normally, Makala is an example of cultural borrowing that refers to a kind of small round ball-like stuff made locally out of either wheat, cassava, beans or banana flour, mixed with yeast and sugar and fried in red oil known as puff-puff (pidgin) or beignet (French). Thus, in the context of corruption, 'makalapaati' has assumed a new meaning suggestive of a tip offered as payment before or after a service is rendered especially during elections. This lexical item is frequently used within political campaigns and ministry of finance. Similarly, 'Soya' refers to roasted meat, often prepared with some smarting aromatic ingredients like pepper. Within the context of corruption in Cameroon, the word soya has assumed a new connotation and is used to indicate the act of offering something to someone to recompense for a service to be rendered or already rendered. To eat Soya signifies a compliance or acceptance to a conditional proposition involving a change of 
opinion. It is derived from the fact that Soya is a meat barbecue prepared with special spices that gives it wonderful flavour and taste. This expression can easily be heard within the public service corridors and in the award of contracts. Other forms of metaphoric use include idiomatic expressions as "oil the mouth", "change camps" "cross the carpet" "bought over" or grease the palms or elbows." Actually, when one is 'bought over' and he 'crosses the carpet,' it is supposed that his 'mouth' is 'oiled' and his behaviour alters. Cameroonians familiar with the pidgin expression 'politiks na njangi', or 'goat di chop for place where dem tie ye' are reminiscent of a then one-time top government official's concept of democracy and governance. The pidgin word 'njangi', refers to any traditional meeting of people where members take turns to carry away the savings. Saying 'njangi na politiks implies that in politics, every player has to contribute by sowing before expecting the harvest. Further notice the pidgin word 'Chop', which means 'to eat' something, signifying that politicians misuse their political positions to extort money from users the same way the 'goat' feeds by virtue of its position. Thus, a corrupt thought will use corrupt language, pretending to communicate by using euphemisms and convoluted phrases. In many societies today, corrupt language has effectively destroyed the bond that holds people together. Corrupt words, perhaps aim at persuading a listener, to a certain extent, create obscurantism, obfuscation, deception, and falsification, with a common goal to darken truth and unsettle people's rights. Doublespeak makes the bad seem good and the negative appear positive. Influence peddling is most often practiced in the world of politics, described by George Orwell as the corruption of thoughts, language, and power (Miller, 2019). From our analysis, one might say corrupt thoughts corrupt language and the society absolutely.

\subsection{Lack of Real Political Will}

Created in 2006, the National Anti-Corruption Commission (CONAC) the Supreme Audit Board (CONSUPE) and the Special Criminal Tribunal (SCT) are organs set up to curb, tract and sanction embezzlers yet they continue to haunt the wrong persons and protecting those huge defaulters. These moves demonstrate attempts by government to address corruption resulting to multiple arrests of top government officials in cases of the embezzlement of astronomical sums of money. Those arrested are scapegoats and many other Cameroon political analysts and academics see nothing but a lack of political will to reduce corruption. The political will of the government to fight against corruption is crucial. It sets the tone, creates the mood and exudes the degree of seriousness needed to engage everyone. Political will is "the demonstrated credible intent of political leaders (elected or appointed leaders, civil society watchdogs, stakeholder groups, etc.) to attack the perceived causes of effects of corruption at a systemic level". Since its creation in 2006, CONAC is still handicapped. A similar situation is that of Opération Épervier (Operation Sparrowhawk - name given by local media for the seasonal arrests of top government officials convicted for corruption) as mere political strategies to eliminate his political opponents or officials from his own political party believed to become a threat to him. Thus, there is a crucial lack of political will to fight against corruption in Cameroon. Even those to sanction defaulters are not exempted from the practice, hence there is no real political will to punish corruption committed by top government officials especially of the ruling party or tribe. In addition, the fight against 
corruption is not affected by the unavailability of economic resources or lack thereof. The lack of political will is not due to a lack of funds, nor legal dispositions. Article 66 of the constitution of 1996 stipulates the declaration of property and sources of income by any civil servant on assumption of function has never been reinforced. This is a credible means to fight against embezzlement, but no civil servant has ever declared any of his assets, under the helpless gaze of Cameroonians. Corruption is not only a political crises. CONSUPE, CONAC, SCT, need to be independent and empowered organs.

Many people believe that corruption in Cameroon is also an economic crises, yet, every day, embezzlement is on the rise. Corruption is a social, moral and linguistic crises. Tackling political corruption, it is important to eradicate moral corruption.

\subsection{Corruption and Moral Values}

To eradicate moral corruption in Cameroon is to foster a change in mental attitudes, social and moral values. Social values are defined as standards, which individuals and social groups employ to define personal goals and essentially shape the nature and form of social order in a collective i.e., what is acceptable and not acceptable, what ought or not to be, what is desirable or non-desirable (Kluckhohn, 1951). Moral education makes one perfect. Education is not aimed at obtaining only a degree, it includes necessary value based teachings which result in character building and social improvement too. It comprises some basic principles such as truthfulness, honesty, charity, hospitality, tolerance, love, kindness and sympathy. Honesty: being truthful and sincere. Integrity: sticking to your moral and ethical principles and values. Kindness: being considerate and treating others well. It provides the basis of decisions of and judgments by the individual: honesty, loyalty, good faith, being responsible. In normal circumstances of conversation, speakers are expected to truthful and sincere in their speech to fulfil the cooperative and politeness principle. Fairness is one basis of law, which helps to govern society and to control individual behaviour. Social morality considers whether an action threatens society's well-being and people must be aware of such malpractice. As a deviant practice, corruption is connected to the rupture and failure to adhere to some conventional social standards and individual behaviour against the cultural norms of society. In fact, the act of occupying authority positions of public or private sector is a social responsibility entrusted to a public servant; being considerate and treating others well is a relevant social code. The committed corruption act negates the laws, regulations, values, and norms of society indicating deviant behaviour and the non-respect of rules and social norms.

Teaching social values in schools will ensure that students have a stronger self-esteem, self-respect and respect to others, and to be tolerance; consequently, it will prevent students in making the wrong decisions. If on the one hand, social values reflect how we relate to society and include justice, freedom, respect, community, and responsibility, moral values, on the other hand, are personal qualities that bear on our character and personality. It is bad to bribe or receive money for public services rendered (based on a value of honesty). Helping a friend is a good thing to do (based on a value of friendship). Values reflect our sense of right and wrong actions. Honesty, caring and compassion, integrity, and personal responsibility are values that help one behave ethically. They help us grow and develop appropriate moral 
values. They help us create the future we want. The decisions we make every day are a reflection of our moral values.

\section{Conclusion}

Much that I have said in this article is that descriptive linguistics and socio-pragmatic analysis highlights on social and linguistic issues. Firstly, lexical structures like verbal phrase structures, references, synonyms, polysemy, euphemism, metaphors, coinages, idioms, borrowings, proverbs are some of the linguistic techniques characteristic of the language of corruption in Cameroon. The values conveyed by these linguistic features fall under the domains of foodstuff and drinks, fauna, human beings and body parts, mailing and transportation as well as abstract realities related to self-benefits.

Secondly, these utterances and expressions collected and analysed as language of corruption are concrete in form, rich in local colour, vivid and appeal in various ways to the listener's mental and visual senses, yet their meanings remain controversial and ambiguous. Corrupt thoughts corrupt language. This language variety has enriched contemporary English vocabulary as Cameroon's multilingual and multi-ethic paradise continue to present fertile grounds for corruption.

Lastly, eradicating corruption in emerging democracies as Cameroon is the shared responsibility of both individual and collective consciousness with strong institutions, the political will and legal determination. Teaching social values in schools and observing them in social life will ensure that people have a stronger self-esteem, tolerance, self-respect and respect for others. There is need for speakers to develop high moral integrity; consequently, it will prevent them from corrupt thoughts and using expressions that hide ill intentions or abuse entrusted office for personal gains. Debating whether social or moral values are important to be taught or not is the wrong issue. Moral values have to be taught to the people to decrease moral decadence and promote linguistic soundness.

In conclusion, despite its devastating personal, political and economic implications to an emerging democracy as Cameroon, corruption discourse has enormously enriched contemporary English vocabulary, adding newly coined or borrowed words from other surrounding languages and developing euphemism and metaphors as new rhetorics of public speaking.

\section{References}

Aik, K. C. (1976). Critical thinking: selected topics for discussion and analysis. Longmans, Singapore.

Amundsen, I. (2019). Political Corruption in Africa. Extraction and power Preservation, Cheltenham, UK and Northampton, MA, Edward Elgar Publishers Ltd. London. https://doi.org/10.4337/9781788972529

Auden, W. H. (1975). The Dyer's Hand (p. 11). London; Faber and Faber. 
Bassey, O. E., \& Utre, E. I. (2007). Corruption and national development in Nigeria: The way forward. Sophia: An African Journal of Philosophy, 9(2), 164-169. https://doi.org/10.4314/sophia.v9i2.38798

Elliott, K. A. (1997). Corruption as an international policy problem: overview and Recommendations. Combating Corruption. World Bank.

Ferdinand de, S. (1966). Course in General Linguistics. Trans. Wade Baskin. New York: McGraw-Hill.

Fometeu, J. (2001). La répression comme moyen de lutte contre la corruption des agents publics au Cameroun. Law and Politics in Africa, Asia and Latin America, 34, 348-360. https://doi.org/10.5771/0506-7286-2001-3-348

Geeraerts, D. (2009). Theories of Lexical Semantics, Published to Oxford Scholarship Online: February 2010. Oxford University Press. https://doi.org/10.1093/acprof:oso/9780198700302.001.0001

God'stime Osariyekemwen, I. (2019). Political Corruption in Nigeria: Implications for Economic Development in the Fourth Republic. Journal of Developing Societies, 35(4), 493-513. https://doi.org/10.1177/0169796X19890745

Halliday, M. A. K., et al.. (2004). Lexicology and corpus linguistics. Continuum.

Hudson, J. (2014). Bribery and Identity: Evidence from Sudan. Bath Economic Research Papers, No 21/14.

Jikong, S., \& Koenig, E. (1983). Language usage in urban centres in Cameroon. In E. Koenig, E. Chia, \& J. Povey (Eds.), A Sociolinguistic Profile of Urban Centres in Cameroon, Los Angeles. Crossroads Press 225 Kinsey Hall.

Kamtchueng, M., \& Martial, L. (2015). Analysing the language of corruption in Sub-Saharan Africa: A case study of some selected countries in West, East and Central Africa.

Kaufmann, D., \& Pedro, V. (2005). Legal Corruption. World Bank. https://doi.org/10.2139/ssrn.829844

Mbangwana, P. N. (1989). Flexibility in Lexical Usage in Cameroon Established English. In Language across cultures: across language NY, Mouton (pp. 319-333). https://doi.org/10.1515/9783110848328.319

Mbangwana, P. N. (2002). English patterns of usage and meaning. Yaoundé: Presses Universitaires de Yaoundé.

Morris, S. D. (1991). Corruption and Politics in Contemporary Mexico. University of Alabama Press, Tuscaloosa.

OECD. (2013). What are bribery and corruption?. In Bribery and Corruption Awareness Handbook for Tax Examiners and Tax Auditors. OECD Publishing, Paris. https://doi.org/10.1787/9789264205376-3-en 


\section{Macrothink}

International Journal of Linguistics

ISSN 1948-5425

2021, Vol. 13, No. 1

Orwell, G. (1981). Politics and the English Language. George Orwell: A Collection of Essays (pp. 156-170). Houghton Mifflin Harcourt Publishing Company.

Paul, G. H. (1989). Studies in the way of words. Cambridge (MA): Harvard University Press.

Schuppert. (2013). Schwer $\mathrm{Zu}$ fassen, Kaum zu verhindern In der Parelleordnung der Korruption zahlen Netzwerke und Besiehungen. WZB Mitteilungen, (140).

Senior, I. (2006). Corruption - The World's Big C. Institute of Economic Affairs, London. https://doi.org/10.2139/ssrn.918474

Simo Bobda, A., \& Mbangwana, P. (1993). An Introduction to Spoken English. Lagos, University of Lagos Press, Lagos.

Thompson, C. (1992). Philosophy and Corruption of Language. Journal of the Royal Institute of Philosophy, 67(259), 19-31. https://doi.org/10.1017/S0031819100039802

Transparency International. (1999). Corruption in Cameroon. Gerddes, Berlin, Germany, June.

Trier, J. (1931). Der deutsche Wortschatz im Sinnbezirk des Verstandes, German vocabulary in the 'sense district' of the mind. Heidelberg, Germany: Winter.

Wittgenstein, L. (1958). Philosophical investigations (2nd ed.). Oxford, UK: Blackwell.

Zekeri, M. (2013). Corruption and Governance in Africa, Global Network for Peace and Anti-Corruption Initiative (GNPAI). Proceedings of the International Academic Conference for Sub-Sahara African Transformation \& Development (Vol. 3, No. 6). 2015-University of Ilorin, Nigeria.

\section{Notes}

Note 1. Michel Bréal's (1897) Essai de sémantique,

Note 2. For more on his views, see Ferdinand de Saussure. (1966) Course in General Linguistics. Cours de Linguistique Générale. Trans. Wade Baskin. New York: McGraw-Hill. First French edition 1916.

Note 3. See Paul Mbangwana (2012: 90)

Note 4. W. H. Auden, The Dyer's Hand, London; Faber and Faber, 1975, p.11

Note 5. See Paul Mbangwana (2002-99)

Note 6. See "Transparency International - CPI - Corruption Perceptions Index 1999". Transparency International. Retrieved March 12, 2019.

Note 7. W. Labov; The study of language in its social context' in his collection of papers; Sociolinguistic Patterns, University of Pennsylvania Press, 1972, section 4

Note 8. Levinson (1983: 24) 


\section{Macrothink}

International Journal of Linguistics

ISSN 1948-5425

2021, Vol. 13, No. 1

Note 9. The 10th edition of the Global Corruption Barometer (GCB)-Africa and "CAMEROON: OVERVIEW OF CORRUPTION AND ANTICORRUPTION". Transparency International. 2016. Retrieved March 20, 2019

Note 10. See B. Ekpenyong \& V. Bassey, 2014, 'Language of Corruption and Anti-corruption in Nigeria', in Lwati: A Journal of Contemporary Research, Issue Vol. 11 No. 2 (2014)

Note 11. God'stime Osariyekemwen Igiebor, Political Corruption in Nigeria: Implications for Economic Development in the Fourth Republic, First Published December 16, 2019, Vol. 35, Issue 2

Note 12. See Momoh,( 2013)

Note 13. Thomson Reuters 'Why corruption is Cameroon's worst-kept secret' 18 Nov 2010, Cameroon profile BBC News 16 January 2015

Note 14. See The Corruption Perceptions Index (CPI 2019) and the annual reports of Transparency International (2008, 2011, 2012 and 2013) and National Commission for the Fight against Corruption (CONAC)

Note 15. Beekers, and B. van Gool (2012)

Note 16. Fometeu, J. (2001). "La répression comme moyen de lutte contre la corruption des agents' publics' au Cameroun"in Verfassung und Recht in Übersee / Law and Politics in Africa, Asia and Latin America. 34: 348-360

Note 17. Caleb Miller, 2019, The Corruption of Thoughts, Language, and Power: George Orwell's View on Government-Controlled Language.

Note 18. Orwell, George. "Politics and the English Language." George Orwell: A Collection of Essays, Houghton Mifflin Harcourt Publishing Company, 1981, 156-170.

Note 20. See the French daily Newspaper Défis Actuels of 29/06/2016, p. 4.

Note 21. See the French daily newspaper Emergence of 29/06/2016, p.5.

Note 22. See the French daily newspaper Ecomatin of 29/06/2016, p.3

\section{Copyrights}

Copyright for this article is retained by the author(s), with first publication rights granted to the journal.

This is an open-access article distributed under the terms and conditions of the Creative Commons Attribution license (http://creativecommons.org/licenses/by/4.0/) 